Columbia Law School

Scholarship Archive

2014

\title{
Tax and Corporate Governance: The Influence of Tax on Managerial Agency Costs
}

David M. Schizer

Columbia Law School, david.schizer@law.columbia.edu

Follow this and additional works at: https://scholarship.law.columbia.edu/faculty_scholarship

Part of the Business Organizations Law Commons, Law and Economics Commons, Public Law and Legal Theory Commons, and the Tax Law Commons

\section{Recommended Citation}

David M. Schizer, Tax and Corporate Governance: The Influence of Tax on Managerial Agency Costs, THE OXFord HandBook of Corporate LaW ANd Governance, JefFrey N. GoRdon \& Wolf-GeORg Ringe, Eds., OXford University Press, 2018; Columbia LaW School Public LAW \& Legal TheORY Working PaPer No. 14-415; Columbia University School of LAW, THE CENTER For LAW \& ECONOMIC Studies Working PaPer No. 491 (2014).

Available at: https://scholarship.law.columbia.edu/faculty_scholarship/2301

This Working Paper is brought to you for free and open access by the Faculty Publications at Scholarship Archive. It has been accepted for inclusion in Faculty Scholarship by an authorized administrator of Scholarship Archive. For more information, please contact scholarshiparchive@law.columbia.edu. 
The Center for Law and Economic Studies

Columbia University School of Law

435 West $116^{\text {th }}$ Street

New York, NY 10027-7201

(212) 854-3739

Tax and Corporate Governance:

The Influence of Tax on Managerial Agency Costs

David M. Schizer

Working Paper No. 491

September 19, 2014

An index to the working papers in the Columbia Law

School Working Paper Series is located at

http://web.law.columbia.edu/law-economic-studies/working-papers 


\title{
Tax and Corporate Governance:
}

\section{The Influence of Tax on Managerial Agency Costs}

\author{
David M. Schizer ${ }^{1}$
}

September 19, 2014

\footnotetext{
${ }^{1}$ Dean Emeritus and the Harvey R. Miller Professor of Law \& Economics, Columbia Law School. This chapter will be published in the Oxford Handbook on Corporate Law and Governance. Copyright David M. Schizer. All Rights Reserved. Helpful comments were received from John Coates, Michael Doran, Victor Fleischer, Michael Graetz, Robert Jackson, and Barbara Lester, as well as from participants at workshops at Columbia Law School and the Tax Club.
} 
Motivating managers to be faithful agents of shareholders is a foundational challenge of corporate governance. The tax system is regularly conscripted in this effort. ${ }^{2}$ In addition, tax also can affect managerial agency costs in ways policymakers do not intend or even recognize. Yet although the tax system influences managerial agency costs in a number of ways, many of these effects have attracted only limited scholarly attention; tax experts rarely focus on agency costs, while corporate experts seldom have detailed knowledge of tax. To fill this gap, this chapter of the Oxford Handbook on Corporate Law and Governance canvasses a broad range of ways that tax influences managerial agency costs, focusing especially on the United States.

In doing so, this chapter has two goals. The first is to help corporate law experts target managerial agency costs more effectively. The analysis here flags when tax is likely to exacerbate agency costs, and when it is likely to mitigate them. Armed with this information, corporate law experts have a better sense of how vigorous a contractual or corporate law response they need. In some cases, a change in the tax law may also be justified. This chapter's second goal, then, is to enhance our understanding of tax rules, shedding light on a set of welfare effects that are important but understudied. After all, tax policy is more likely to enhance welfare if policymakers weigh all possible welfare effects, including managerial agency costs.

Overall, the U.S. tax system's record in influencing agency costs is not encouraging. After all, the system's priority is not to reduce agency costs, but to raise revenue efficiently and fairly. Government tax experts do not usually have the expertise or motivation to tackle corporate governance problems. Tax also is a poor fit because it typically applies mandatorily and uniformly, while responses to agency cost should be molded to the context. For example, promoting stock options or leverage will be valuable in some settings, but disastrous in others. There also are political hurdles to be overcome. Accordingly, when tax rules target agency costs, the results often are poorly tailored or even counterproductive. This is all the more true when tax influences agency costs by accident, instead of by design.

Fortunately, the effects are not all bad. On the positive side of the ledger, U.S. tax rules encourage performance-based pay both intentionally and inadvertently, albeit in blunt ways. ${ }^{3}$ In addition, by taxing intercompany dividends, the U.S. keeps block-holders in one firm from indirectly controlling other firms. In so doing, tax discourages "pyramidal" ownership, which is a common source of agency costs in other jurisdictions. ${ }^{4}$ U.S. tax rules also encourage leverage, which usually (but not always) mitigates managerial agency costs. ${ }^{5}$ Likewise, some tax rules

\footnotetext{
${ }^{2}$ Steven A. Bank, Tax, Corporate Governance, and Norms, 61 WASH. \& LEE L. REV. 1159, 1162 (2004) (describing U.S. tax as a "means to preempt the traditional state role in the regulation of corporations without actually establishing a system of federal incorporation").

${ }^{3}$ David M. Schizer, Executives and Hedging: The Fragile Legal Foundation of Incentive Compatibility, 100 COLUM. L. REV. 440 (2000) (hereinafter Executives and Hedging)..

${ }^{4}$ Randall Morck, Daniel Wolfenzon, \& Bernard Yeung, Corporate Governance, Economic Entrenchment, and Growth, 43 J. ECON. LIT. 655 (2005).

${ }^{5}$ See generally John R. Graham, Taxes and Corporate Finance: A Review, 16 REV. FIN. STUD. 1075 (2003).
} 
favor long-term ownership, ${ }^{6}$ which can motivate shareholders to monitor management more carefully. The need to disclose financial information on a corporate tax return can also discipline management. ${ }^{7}$ Discouraging the use of offshore accounts and off-balance sheet entities, moreover, can keep managers from cheating shareholders, as well as the fisc. ${ }^{8}$

On the other side of the ledger, U.S. tax rules can be a reason (or excuse) for flawed pay. ${ }^{9}$ Managers also can use tax as a pretext to retain earnings, and also to oppose takeovers that put their jobs at risk. Tax also can be invoked to justify "empire building" acquisitions as well as hedging, each of which appeals more to undiversified managers than to diversified shareholders. ${ }^{10}$ U.S. tax rules also encourage firms to incorporate offshore or to use passthrough entities, even though these steps can weaken shareholders' corporate law rights. ${ }^{11}$

This chapter concentrates on public companies, where the separation of ownership and control is especially pronounced. The focus is on "C-corporations," since pass-through entities (such as S-corporations, LLCs and partnerships) are generally ineligible for public trading.

While the topic here is how tax can affect agency costs, causation also can run the other way: that is, agency costs can affect tax. For instance, a manager whose bonus is based on accounting earnings might reject a tax planning strategy that reduces book earnings. If so, agency costs (and accounting rules) are serving as nontax constraints on tax planning (or "frictions"). Frictions are not the focus of this chapter, but a few are mentioned along the way.

After Part I assesses why tax is an imperfect vehicle for mitigating managerial agency costs, Part II assesses how tax influences the compensation of managers. Part III analyzes how tax affects management decisions about distributing and investing firm resources. Part IV considers how the tax system influences the ability and incentives of shareholders to monitor management, as well as how the tax system itself monitors managers. Part V is the conclusion.

\section{An Imperfect Vehicle for Mitigating Managerial Agency Costs}

Although there is a plausible theoretical case for using tax to influence managerial agency costs, tax is likely to be an imperfect vehicle for a number of reasons.

\footnotetext{
${ }^{6}$ See David M. Schizer, Realization as Subsidy, 73 N.Y.U. L. REV. 1549 (1998) (hereinafter "Realization as Subsidy”).

${ }^{7}$ Marjorie E. Kornhauser, Corporate Regulation and the Origins of the Corporate Income Tax, 66 IND. L. J. 53, 133-34 (1990-1991).

${ }^{8}$ Mihir A. Desai \& Dhammika Dharmapala, Tax and Corporate Governance: An Economic Approach 14-15, in TAX AND CORPORATE GOVERNANCE (Wolfgang Schön ed. 2008) (tax system and shareholders have a common interest in targeting "complexity and obfuscation" that can be used both for tax avoidance and for "earnings manipulation . . , the concealment of obligations . ., or outright diversion").

${ }^{9}$ David M. Schizer, Tax Constraints on Indexed Options, 149 U. PA. L. REV. 1941 (2000-2001) (hereinafter "Indexed Options").

${ }^{10}$ See, e.g., John R. Graham \& Daniel A. Rogers, Do Firms Hedge in Response to Tax Incentives? 57 J. FIN. 815 (2002) (hereinafter “Do Firms Hedge in Response to Tax Incentives?”).

${ }^{11}$ Mihir A. Desai \& James R. Hines, Jr., Expectations and Expatriations: Tracing the Causes and Consequences of Corporate Inversions, 55 NAT. T. J. 409 (2002).
} 


\section{A. Agency Costs, Free Riding, and Externalities}

In theory, a tax rule that successfully enhances corporate governance is appealing, since poor governance leads to suboptimal allocations of capital, less innovation, inflated costs, and slower economic growth. Of course, a government role is unnecessary if shareholders are effective in monitoring management. Yet although monitoring is in their collective interest, individual shareholders would prefer to free ride on others. As a result, monitoring usually is undersupplied. By compensating for this free riding, the government can enhance welfare.

\section{B. An Existing and Potentially Persuasive Mechanism to Influence Managers}

Even though there is a plausible case for government intervention, is tax the right instrument? One advantage is that managers pay attention to tax. They want to reduce their own tax liabilities as well as the firm's tax bill (as long as doing so isn't costly to them). Using this existing mechanism for communicating government policy to management avoids the costs of building another from scratch.

Of course, tax considerations are not always persuasive to managers. While executives want to reduce the firm's tax bill (and, of course, their own), they have other priorities as well, such as maximizing the firm's accounting earnings. Indeed, managers sometimes favor book over tax when these goals are in conflict. ${ }^{12}$

\section{Mismatch in Institutional Focus and Expertise}

Another limitation of using tax to constrain agency costs is the mismatch in institutional focus and expertise. Many government tax experts do not have deep experience with key corporate governance problems or potential solutions. Most do not view these issues as central to their mission. This lack of focus and expertise helps explain why some tax rules targeting agency costs pursue misguided goals, while others pursue sensible goals in poorly tailored ways.

\section{Political Constraints and Symbolic Legislation}

These deficiencies sometimes derive also from political dynamics. In enacting these rules, Congress often responds to critical media reports about a particular practice. At the same time, organized interest groups exert offsetting pressure to keep this response limited. A politically expedient reaction, then, is to target the abuse, while allowing an obscure way for it to continue. Since these rules and the targeted practices are usually complex, unsophisticated

\footnotetext{
${ }^{12}$ See, e.g., John R. Graham, Michelle Hanlon, Terry Shevlin \& Nemit Shroff, Incentives for Tax Planning and Avoidance: Evidence from the Field, ACCOUNTING REV. (forthcoming 2014) (surveying 600 publicly-traded firms and finding that top management at $84 \%$ care at least as much about the GAAP earnings as they do about taxes); Douglas A. Shackelford \& Terry Shevlin, Empirical Tax Research in Accounting, 31 J. ACCOUNTING \& ECON. 321 (2001) (noting that negative effect on reported earnings serves as constraint on tax planning). But Cf. Michelle Hanlon, Edward Maydew \& Terry Shevlin, Book-Tax Conformity and the Information Content of Earnings, U. Mich. Working Paper (2005) (noting that firms responded to a change in US tax law, which enhanced book-tax conformity, by reporting lower earnings in order to reduce their tax bill).
} 
constituents are unlikely to know how narrow the response was. As a result, government officials can claim credit with these constituents without alienating affected interest groups.

\section{E. Poorly Tailored Scope: The Drawbacks of Uniform and Mandatory Rules}

These political constraints, combined with the mismatch in expertise and institutional focus, tend to breed poorly tailored rules. Some are easy to avoid. A modest tweak allows a firm or manager to dodge a well-deserved penalty or claim an unwarranted benefit. Other measures are too broad. A practice that compounds agency costs in one setting may mitigate them in another. The answer can vary by industry, firm size, dispersion of share ownership, overall market conditions, and so forth. The tax authorities may not be sensitive to these differences. In addition, unlike corporate law, whose default rules can be tailored to a firm's circumstances, tax rules usually are mandatory and uniform. In principle, tax rules could vary with the context or be waivable (e.g., by a board or shareholder vote), but this sort of tax rule is rare.

In navigating these tax rules, firms typically rely on the ingenuity of law firms, compensation consultants, and other professional advisors. Their services do not come cheap, and shareholders usually are footing the bill. These planning costs are regrettable even when the goal is to reduce agency costs - and all the more so when the opposite goal is pursued.

\section{F. The Magnitude of the Penalty or Subsidy}

In targeting agency costs, tax subsidies or penalties must have not only the right scope but also the right magnitude. In other words, the amount has to be calibrated to the relevant externality. Unfortunately, though, government tax experts are unlikely to have the expertise to pick the right level, especially if the externality varies with the context.

An additional problem is that the level varies with the taxpayer's marginal rate when a deduction or exclusion is used. ${ }^{13}$ Yet marginal rates obviously are not set with managerial agency costs in mind. For example, a firm with substantial net operating losses, which would not pay taxes anyway, could be immune from the penalty. If anything, this seems backwards. Firms may be unprofitable because of agency costs, and these firms should not be left out. Moreover, to the extent that marginal rates otherwise vary with income - as is more true of LLCs (subject to individual rates) than corporations (subject to largely flat corporate rates) in the U.S. - the penalty or subsidy is lower for less profitable firms. Credits and some excise taxes can avoid these problems, as can rules that affect the tax bill of the manager instead of the firm.

\section{G. Imposition on the Wrong Party}

\footnotetext{
${ }^{13}$ A deduction is worth the amount of tax that is avoided, which in turn depends on the taxpayer's marginal rate. If a firm has a $35 \%$ marginal rate, then a dollar of deductions avoids 35 cents of tax. If the marginal rate is $25 \%$, a dollar of deductions is worth only 25 cents.
} 
There is another reason to target the manager instead of the firm: the manager is more likely to pay attention. After all, a manager who wastes the firm's money on lavish offices or travel accounts presumably will not mind inflating the firm's tax bill. Since tax is complex and esoteric, shareholders may not notice. In contrast, managers usually will know (and care) about their own tax liabilities. Admittedly, the latter incentive is neutralized if the firm grosses the manager up. But, at least in some cases, a gross-up could discourage the relevant practice by calling more attention to it.

\section{H. Accidental Effects}

These issues arise not only when the government uses the tax law deliberately (so-called "Pigouvian" measures), but also when effects are unintended. For example, a goal pursued by the tax system, such as reducing compliance costs or blocking a form of tax planning, could end up affecting agency costs as well. In some cases, government tax experts may not even be aware of these accidental effects. When they are, they often won't consider them their problems to solve.

This mismatch in expertise and mission is a problem, then, not only because tax experts are unlikely to craft a successful Pigouvian measure, but also because they are unlikely to consider managerial agency costs when making run-of-the-mill tax policy decisions. Tax experts may overvalue a tax rule that fares well on traditional tax policy criteria but has adverse corporate governance effects. Likewise, they may undervalue a rule that is weak on traditional criteria but diminishes managerial agency costs. Of course, agency costs are not a trump that always should override these traditional tax policy considerations, but they should not be neglected either.

For parallel reasons, an interdisciplinary perspective is also valuable for corporate governance experts. For example, if a change in tax law exacerbates agency costs, corporate experts should consider an offsetting change in contracts, corporate law, or securities law. Admittedly, though, this sort of coordination is a delicate matter, which requires enough tax expertise to know of the change and its likely effect on agency costs.

There are good reasons, then, for the government to develop more interdisciplinary expertise, although it may be optimistic to expect them to do so. Practitioners and academic commentators can play a valuable role in identifying unintended effects and suggesting reforms to respond to them.

\section{Randomness and Instability}

Just as tax effects can be enacted unintentionally, they also can be repealed unintentionally. The tax rule can change for policy or political reasons having nothing to do with corporate governance. When this happens, the good news is that executives are unlikely to 
capture the process. The bad news is that changes are essentially random. They are as likely to exacerbate agency costs as to mitigate them.

\section{Compensation}

To see how these dynamics play out, we turn to a key setting in which tax influences agency costs: executive compensation. In the U.S., a number of Pigouvian tax provisions regulate executive pay. Some pursue worthy goals in imperfect ways, while others are misguided. There also are unintended effects. In some cases, the tax system has its own reasons to target activity that could compound agency costs. In other cases, the effects are essentially an accident. Ironically, the unintended effects have a somewhat better track record, a reality that does not inspire confidence.

\section{A. Pigouvian Provisions Encouraging Performance-Based Pay}

\section{Performance-Based Pay: A Standard Response to Agency Costs}

In general, managers should earn more for doing good work, but this is easier said than done. If cash bonuses reward executives for meeting specified goals, the right goals must be set and progress must be measured in ways that are hard to manipulate. Alternatively, equity compensation can motivate executives to raise the stock price, but it has three familiar problems. First, equity compensation can tempt managers to use accounting gimmicks (or fraud) to raise the stock price. Second, this pay often rewards executives for general market increases. Third, stock and options create different incentives. Unlike stockholders, option-holders generally do not benefit from dividends, so option grants can exacerbate agency costs by discouraging dividends. ${ }^{14}$ Option grants also encourage more risk-taking than stock grants. ${ }^{15}$ This incentive often is valuable, since managers tend to be more risk-averse than shareholders. Yet options sometimes induce too much risk.

The right mix of stock, options, and bonuses, then, depends on a broad range of contextspecific factors, including the business's maturity, its debt-equity ratio, general market conditions, the executive's overall portfolio and risk preferences, the extent of shareholder monitoring, and the type of industry (since risk-taking at banks, for instance, creates unique concerns). One-size-fits-all answers will not be optimal, and sometimes are quite flawed.

\section{Tax Deferral for Equity Compensation}

\footnotetext{
${ }^{14}$ Richard A. Lambert, William N. Lanen \& David F. Larcker, Executive Stock Option Plans and Corporate Dividend Policy, 24, J. FIN. QUANT. ANAL. 409 (1989) (noting that executive stock options lose value when firms pay dividends and thus create incentives to retain earnings or repurchase shares).

${ }^{15}$ Wm. Gerard Sanders \& Donald C. Hambrick, Swinging for the Fences: The Effects of CEO Stock Options on Company Risk Taking and Performance, 50 ACADEMY OF MAN. J. 1055 (2007).
} 
Compared to cash compensation, U.S. tax on equity compensation generally is deferred. ${ }^{16}$ During this deferral period, the employer can invest the cash it otherwise would have used to pay cash compensation. When the firm pays tax on these investments, it in effect serves as a surrogate taxpayer for the employee. ${ }^{17}$ This arrangement is tax-advantaged, as Daniel Halperin and Alvin Warren have shown, "if the employer earns an after-tax return on the deferred compensation that is higher than that available to the employee."18 This can happen, for instance, if the firm uses this cash to buy back its stock (e.g., to hedge its obligation on the executive compensation), since (unlike executives) firms are not taxed on gains in their own stock. ${ }^{19}$ In other cases, though, the firm cannot earn a higher after-tax return than the executive. For example, if the firm invests in stock of a third party, its tax rate could be higher than the executive's tax rate on the same investment. ${ }^{20}$ In this case, the arrangement is not tax advantaged, once all the parties' tax burdens are considered. ${ }^{21}$

\section{Favoring Bonuses and Stock Options: A Worthy Goal Sometimes, But Not Always}

Section $162(\mathrm{~m})$ accords a clearer tax advantage to equity compensation (and other performance-based pay), but in a blunt way. It denies a deduction for pay above $\$ 1$ million to certain senior executives. $^{22}$ When enacted in 1993, Section 162(m) was explained as a limit on the amount of pay. Indeed, if managers capture the process that sets their pay, tax is one of the instruments that can be deployed in response. ${ }^{23}$

Nevertheless, the main effect of Section 162(m) has been on the type of pay, since it offers a widely-used exception for "performance-based compensation." 24 To qualify, pay must be "solely on account of the attainment of . . pre-established, objective performance goals," and attaining these must be "substantially uncertain." 25 In response, firms shifted from cash compensation to stock options and stock appreciation rights ("SARs") in the $1990 \mathrm{~s},{ }^{26}$ something

\footnotetext{
${ }^{16}$ See 26 U.S.C. $\$ 83$ (a) (tax on restricted stock grants generally is deferred until the shares vest, and tax on option grants is deferred until they are exercised). All references to sections are to the Internal Revenue Code of 1986, as amended.

${ }^{17}$ This is an example of what Professors Halperin and Warren call "counterparty deferral." Daniel I. Halperin \& Alvin C. Warren, Understanding Income Tax Deferral Harvard Public Law Working Paper No. 14-06, Available at SSRN:http://ssrn.com/abstract=2376314 (forthcoming 2014 TAX L. REV.).

${ }^{18}$ Id.

${ }^{19}$ Section $162(\mathrm{~m})(4)(\mathrm{C})$.

${ }^{20}$ Under current law, corporate capital gains generally are taxed at 35\%, while the individual (long-term) capital gains rate is generally lower.

${ }^{21}$ See David I. Walker, Is Equity Compensation Tax Advantaged?, 84 B.U. L. REV. 695, 731 (2004) ("The fisc actually comes out ahead versus cash compensation, since the cost of the employee-level exemption ... is more than offset by the tax on the employer-level investment. ...").

${ }^{22}$ Section $162(\mathrm{~m})$.

${ }^{23}$ See, e.g., David I. Walker, A Tax Response to the Executive Pay Problem, 93 B.U. L. REV. 325 (2013) (proposing surtax on executive pay combined with investor tax relief).

${ }^{24}$ Section $162(\mathrm{~m})(4)(\mathrm{C})$.

25 Treas. Reg. 1.162-27(e).

${ }^{26}$ Nancy L. Rose \& Catherine Wolfram, Regulating Executive Pay: Using the Tax Code to Influence Chief Executive Officer Compensation, 20 J. LABOR ECON. 138 (2002) (finding decrease in rate of growth of cash
} 
they were doing for other reasons anyway. Options and SARs qualify as long as they are not inthe-money when issued, as do earnings-based bonuses if the target is challenging enough. ${ }^{27}$

Section $162(\mathrm{~m})$ has introduced potentially useful process requirements. A committee of independent directors must set performance-based targets and confirm that they have been met. ${ }^{28}$ In addition, shareholders must vote to approve material terms. ${ }^{29}$ These requirements could mitigate agency costs in some cases.

Yet Section $162(\mathrm{~m})$ has also distorted compensation practices in unfortunate ways. For example, the formula for computing performance-based pay can provide discretion to reduce pay, but not to increase it. ${ }^{30}$ This asymmetry can justify (or rationalize) a more generous formula, since the resulting number can be cut but not raised. If compensation committees then reduce the number, they can claim to be holding the line on pay — by offering less than was authorized - even as they award a substantial increase over the prior year.

Section $162(\mathrm{~m})$ also creates a preference for options and SARs over stock, which is not always advisable. Restricted stock grants do not qualify as performance-based — and thus are not deductible - unless employees earn the stock grant only by satisfying a performance-based standard (e.g., an earnings-based bonus paid in stock). In deciding whether to compensate executives with stock or options, a key question is how much risk we want executives to take. Unfortunately Section $162(\mathrm{~m})$ does not account for the context-specific factors bearing on this judgment In addition, as noted above, option grants may discourage firms from paying dividends. ${ }^{31}$

Unfortunately, section 162(m) may even have motivated some firms to commit fraud. By favoring options that were at-the-money when granted, the rule creates a tax incentive to lie about the grant date. Many firms have "backdated" options to conceal that the options were inthe-money when granted. ${ }^{32}$

compensation after 1993); Todd Perry \& Marc Zenner, Pay for Performance? Government Regulation and the Structure of Compensation Contracts, 62 J. FIN. ECON. 453 (2001) (enactment of 162(m) contributed to growth in equity compensation); Brian Hall \& Jeffrey B. Liebman, The Taxation of Executive Compensation, 14 Tax Policy and the Economy (James Poterba ed. 2000); M. Johnson, S. Nabar \& S. Porter, Determinants of Corporate Response to Section 162(m). U of Mich. Working Paper (1999) (of 297 publicly held U.S. firms that paid more than $\$ 1$ million of compensation in 1992, 54 percent preserved deductibility; of these, 78 percent did so through plan qualification)

${ }^{27}$ A further advantage of at- or out-of-the-money options and SARs is that they generally are exempt from the onerous requirements of Section 409A for deferred compensation.

${ }^{28}$ Treas. Reg. $1.162-27(\mathrm{e})(3) \&(\mathrm{e})(5)$.

${ }^{29}$ Treas. Reg. 1.162-27(e)(4).

${ }^{30}$ Treas. Reg. 1.162-27(e)(2)(iii)(A).

${ }^{31}$ See supra Part II.A.1.

${ }^{32}$ See Jesse M. Fried, Option Backdating and its Implications, 65 WASH. \& LEE L. REV. 853, 854 (2008) ("Evidence has emerged that several thousand publicly traded firms used hindsight to secretly backdate stock option grants. ..."). Before 2005, firms also had an accounting reason to avoid in-the-money grants. These had to be expensed, while at-the-money options did not. Since 2005, all option grants must be expensed. Id. at 859 . 


\section{Conventional Options Instead of Indexed Options: Worthy Goal But Imperfect Means}

Another problem with Section 162(m) is that it treats options as performance-based even when they are not - or, at least, when a significant source of their value is not. Assume XYZ stock is trading at $\$ 100$, and executives are given options to buy shares at $\$ 100$. Let's say that the market as a whole increases by $30 \%$, while XYZ shares rise by only $10 \%$. Even though XYZ has significantly underperformed the market, executives still earn $\$ 10$ per share. In contrast, if the overall market declines by $30 \%$, but XYZ declines by only $1 \%$, XYZ has significantly outperformed the market. Nevertheless, executives earn nothing on these conventional options.

To avoid this problem, the exercise price should not be a fixed number. Instead, it should float with the overall market or with the performance of industry competitors. ${ }^{33}$ For example, the exercise price on an "indexed" option can be $1 / 20^{\text {th }}$ of the S\&P 500 (e.g., if the S\&P 500 is 2000 when the option is granted). Yet even though an indexed option is more performancebased, Section 162(m) does not distinguish between it and a conventional option.

On the contrary, Section 162(m) actually favors conventional options over indexed options in a range of ways. First, the process requirements for conventional options are more relaxed than for indexed options. ${ }^{34}$ Second, conventional options offer pay that is not really performance-based, but is still deductible. These options offer two sources of value: a firmspecific bet, which is performance-based, and a general market bet, which is not. As a result, compensating executives with conventional options is like giving them indexed options along with extra cash that is invested in a diversified portfolio. ${ }^{35}$

Finally, there is even an argument that indexed options cannot qualify as "performancebased pay," although the better view is that they can. The concern derives from Section 162's legislative history, which suggests that stock options are performance-based only if they reward increases in the stock price. ${ }^{36}$ If this is the rule, indexed options may not pass muster; they

\footnotetext{
${ }^{33}$ Schizer, Indexed Options, supra note Error! Bookmark not defined., at 1941.

${ }^{34}$ Conventional options comply with the so-called "performance goal requirement" if they are issued at-the-money or out-of-the-money, so that "the amount of compensation the employee could receive is based solely on an increase in the value of the stock after the date of the grant or award." 1.162-27(e)(2)(vi). In contrast, this language - and the process short-cut it provides - does not apply to indexed options; rather, indexed options offer a return if the stock prices increases more (or decreases less) than the index, and not "solely" if the stock price increases. As a result, indexed options are subject to the more rigorous process requirements governing earnings based bonuses.

${ }^{35}$ Assuming this market exposure represents half of a conventional option's value, a package of $\$ 1$ million in conventional options and $\$ 1$ million in cash is roughly comparable to one of $\$ 500,000$ in indexed options and $\$ 1.5$ million of cash, of which $\$ 500,000$ is invested in the stock market. A difference is that the executive loses the $\$ 500,00$ stock market portfolio if the firm-specific bet is sufficiently unsuccessful. In other words, if the firm declines in value in a rising stock market, the executive gets no return. This is different from a package composed of an indexed option and a separate investment in the S\&P, since the executive would still have the latter even if the former expires worthless.

${ }^{36}$ See H.R. Conf. Rep. No. 103-213, at 587 (1993) (treating stock options as performance-based if the return is "based solely on an increase in the corporation's stock price," but not performance-based "if the executive is otherwise protected from decreases in the value of the stock (such as through automatic repricing)").
} 
reward executives whose stock price declines, as long as it declines less than the index. Yet unlike the legislative history, the statute itself says nothing about this issue. Instead, it merely requires compensation to be "payable solely on account of the attainment of one or more performance goals." 37 Indexed options should satisfy this requirement. Their performance goal is that the stock price has to outperform the index. ${ }^{38}$

\section{Incentive Stock Options: Worthy Goal But Imperfect Means}

Another U.S. tax rule favoring performance-based pay is Section 422, which offers capital gains tax treatment for so-called incentive stock options ("ISOs"). Under current rates, executives are taxed at $23.8 \%$ on ISOs ( $20 \%$ on capital gains and, in some cases, an additional $3.8 \%$ net investment tax), instead of the top bracket of $39.6 \%$, as long as holding period and other requirements are satisfied. ${ }^{39}$ Yet this tax advantage is offset — often, more than offset by a tax disadvantage to the firm: ISOs are not deductible. ${ }^{40}$ For each dollar, the firm gives up 35 cents to save employees 15.8 cents. ISOs are not truly tax advantaged, then, unless the employer cannot use the deduction, as is the case with a tech startup that is not yet profitable.

Even so, ISOs are used beyond this narrow setting presumably because managers care more about their taxes than the firm's taxes. In theory, a firm could instead persuade shareholders to forgo capital gains treatment by "grossing them up" with a larger (but deductible) grant that is taxed as ordinary income. ${ }^{41}$ But managers may be reluctant to accept this trade because the gross-up would be more visible to shareholders than the lost deduction. As a result, even though the tax law limits the size of ISO grants, executives often receive the largest allowable grant. Ironically, a form of pay that is supposed to target agency costs is probably overused for agency cost reasons.

\section{Deferred Compensation: Worthy Goal But Imperfect Means}

Managers are supposed to be faithful agents not only to shareholders but also to creditors. A familiar concern is that when insolvency is likely, executives take unwise risks hoping to save the company (and their jobs). If the bet doesn't pay off, creditors will be hurt, but the executive

\footnotetext{
${ }^{37}$ Section $162(\mathrm{~m})(4)(\mathrm{C})$.

${ }^{38}$ If this interpretation is not fully reassuring, the option's terms can be adjusted to avoid rewarding executives whose stock price declines. A (partially) indexed option can reward executives if the firm outperforms the index, but only if the stock price also appreciates. For example, if the stock price is $\$ 100$ and the S\&P 500 is 2000 on the grant date, the exercise price can be the greater of: (a) $1 / 20^{\text {th }}$ of the S\&P 500; and (b) $\$ 100$.

${ }_{39}$ For example, the taxpayer must satisfy a 12-month holding period for the option and another 12-month holding period for the stock, and the options must not be issued in-the-money.

${ }^{40}$ In contrast, nonqualified options (NQOs) allow the firm to deduct the same amount that employees include as ordinary income, which generally is the difference between the stock price and the exercise price when the option is exercised.

${ }^{41}$ On an ISO grant of 100 shares, each dollar of share appreciation gives the executive $\$ 80$, but it costs the firm a full $\$ 100$ (because this cost is not deductible). If instead the executive receives a nonqualified grant of 140 shares, both the executive and the firm are better off: the executive has $\$ 84.56$ ( $\$ 140$ minus $\$ 55.44$ in tax), while the firm spends only $\$ 91$ (since it can deduct \$49).
} 
has little to lose. ${ }^{42}$ In response, the interests of managers and creditors can be aligned by giving managers deferred compensation so they become unsecured credits. ${ }^{43}$ A tax preference can promote deferred compensation by offering higher after-tax returns if pay is deferred. ${ }^{44}$

Even so, deferred compensation reduces agency costs only if structured properly. To expose this pay to the risks of bankruptcy, it should not be paid too soon after the executive retires. ${ }^{45}$ Yet U.S. executives can accelerate this pay by incurring a $20 \%$ penalty. ${ }^{46}$ They will be willing to incur this cost if bankruptcy is imminent, which means acceleration is most likely when it is most problematic. ${ }^{47}$ Deferred compensation also should be disclosed clearly, and it should not be performance-based or encourage executives to take risks. ${ }^{48}$ However, according to Robert Jackson and Colleen Honigsberg, these conditions are often violated. ${ }^{49}$

\section{Golden Parachutes: Misguided Goal}

The U.S. also imposes a Pigouvian tax on golden parachutes, or payments to managers when their employer is sold. Presumably, the concern is that parachutes make managers too willing to accept acquisitions. ${ }^{50}$ Yet this provision neglects the strong management interest in resisting acquisitions, which can eliminate their jobs. In tempering this self-interested impulse, parachutes align shareholder and management interests in many cases, and should not be discouraged. $^{51}$

\footnotetext{
${ }^{42}$ See also Chenyang Wei \& David Yermack, Investor Reactions to CEOs' Inside Debt Incentives 24 REV. FIN. STUD. 3813-40 (2011); Frederick Tung \& Xue Wang, Bank CEOs, Inside Debt Compensation, and the Global Financial Crisis (Boston Univ. School of Law Working Paper No. 11-49) (December 11, 2012), available at http://papers.ssrn.com/sol3/papers.cfm?abstract_id=1570161.

${ }^{43}$ Michael C. Jensen \& William H. Meckling, Theory of the Firm: Managerial Behavior, Agency Costs and Ownership Structure, 3 J. FIN. ECON. 305 (1976) (if a firm is capitalized with equity and debt, an optimal pay package provides both).

${ }^{44}$ In the U.S., for instance, nonqualified plans are taxed favorably if the employer's tax rate on investment earnings is lower than the employee's rate. Halperin \& Warren, supra note 17, at 12-13 ("any benefit from nonqualified deferred compensation is due entirely to the difference between the employer's and the employee's after-tax rate of return on income earned by investing the deferred amount").

${ }^{45}$ Robert J. Jackson, Jr. \& Colleen Honigsberg, The Hidden Nature of Executive Retirement Pay 100 VA. L. REV. 479, 486 (2014) ("for retirement arrangements to serve as inside debt the executive must, in the event of bankruptcy, recover amounts comparable to those recovered by the company's other unsecured creditors").

${ }^{46}$ Section 409A(a)(1)(B).

${ }^{47}$ Jackson \& Honigsberg, supra note 45, at 503 ("But the provision instead merely limits accelerations to cases in which executives are most certain that bankruptcy is coming. ...").

${ }^{48} I d$. at 486 ("Unlike bonuses or stock-based pay, which reward managers for taking risk, fixed payments encourage executives to avoid risks that might render the firm insolvent"). "

${ }^{49} I d$. at 506 (estimating that $\$ 32,500$ of annual compensation is hidden through deferred compensation for the average executive in their sample).

${ }^{50}$ David W. Leebron, Games Corporations Play: A Theory of Tender Offers, 61 N.Y.U. L. REV. 153, 183 n.105 (1986) (managers may not drive a hard enough bargain); Ronald J. Gilson, Value Creation by Business Lawyers: Legal Skills and Asset Pricing, 94 YALE L. J. 239, 285 n.114 (1984) (noting perverse incentives in parachutes).

${ }^{51}$ Daniel R. Fischel, Organized Exchanges and the Regulation of Dual Class Common Stock, 54 U. CHI. L. REV. 119, 137 (1987) (parachutes are a way to protect managers for developing firm-specific skills; John C. Coffee, Jr., Shareholders Versus Managers: The Strain in the Corporate Web, 85 MICH. L. REV. 75-76 (1986) (parachutes can be a way to recruit quality management in active takeover environment).
} 
Unfortunately, Section 4999 imposes a 20\% excise tax on "excess parachute payments," which generally are the excess over three year's salary. This penalty applies not only to cash payments, but also to the accelerated vesting of stock and options. These grants appreciate if there is an acquisition premium, so this appreciation - a significant percentage of most parachutes $^{52}$ - increases the excise tax bill. Yet it makes no sense to penalize managers for a deal premium that benefits shareholders. ${ }^{53}$

The tax penalty on parachutes is misguided also in imposing costs on the firm, instead of on management. Experts must be retained to value this accelerated vesting, and this difficult and costly process is funded by shareholders. In addition, Section $280 \mathrm{G}$ disallows the firm's deduction for excess parachute payments (as well as payments "grossing up" managers for the excise tax). But if managers really put their own interests ahead of the firm, as this regime assumes, why would a tax penalty on the firm deter them?

\section{B. Shared Interests: Hedging Stock Options and Suspicion of Hedged Positions}

Although the focus so far has been on tax effects that are intentional, unintended effects can also be important. In fact, one of U.S. tax law's main contributions to corporate governance discouraging executives from hedging their stock options - arose by accident. Options are supposed to reduce agency costs by rewarding executives when the firm's stock price rises, but executives can thwart this goal by neutralizing this exposure with derivatives. ${ }^{54}$ Although firms should have contractual bans on hedging, only some do. U.S. securities laws can require reporting, but it can be obscure and is required only in some cases.

Instead, U.S. tax law plays an important but largely unintended role. ${ }^{55}$ Hedging stock options is unappealing because it can trigger tax even when executives have no economic gain. Although the relevant rules are technical, the executive's problem is that stock option gains are taxed as ordinary income, while (offsetting) hedging losses generally are treated as capital losses, which cannot shelter ordinary income. ${ }^{56}$ For example, assume an executive's options appreciate by $\$ 1$ million after she hedges them. She has an extra $\$ 1$ million of ordinary income, which is matched by a $\$ 1$ million capital loss on the hedge that cannot be deducted from ordinary income. As a result, she owes an extra $\$ 396,000$ in tax, but without a corresponding economic gain. Of

\footnotetext{
52 Jay C. Hartzell, Eli Ofek \& David Yermack, What's In It For Me? CEOs Whose Firms Are Acquired, 17 REV. FIN. STUD. 37, 45 (2004) (noting that "mean CEO's gains from stock and option appreciation are just under \$5 million," median gains "are a little over $\$ 1.5$ million," and "[t]hese sources of wealth represent the largest component of the overall gains obtained by sample CEOs").

${ }^{53}$ Id. ("CEOs obtain [equity appreciation] only because shareholders as a group receive a premium price from the buyer. Therefore, to the extent that a conflict of interest exists between CEOs and shareholders in connection with merger negotiations, the conflict must arise from" other components of parachutes).

${ }^{54}$ For instance, an executive who receives a compensatory option to buy 10,000 shares at $\$ 100$ might sell a similar over-the-counter call option to a derivatives dealer so the two positions essentially cancel each other out.

${ }^{5}$ Schizer, Executives and Hedging, supra note 3, at 440.

${ }^{56}$ Only a modest amount of capital loss can be used to offset ordinary income each year. Some hedges generate ordinary losses, but involve comparable problems. See generally Schizer, Executive and Hedging, supra note 3.
} 
course, she still has $\$ 1$ million of capital losses, but she cannot use them unless she has $\$ 1$ million of capital gains elsewhere in her portfolio. ${ }^{57}$ Unlike the Pigouvian measures discussed above, the relevant tax rules here are not meant to target managerial agency costs. Rather, tax systems have their own reasons to penalize offsetting positions. In a realization-based system, gains and losses can be timed in ways that reduce tax; in response, capital loss and other limitations are supposed to impede this tax planning. These rules were added by the tax system for its own reasons, but they end up playing a valuable corporate governance role.

Even so, these rules are incomplete and potentially unstable. They apply only if equity compensation is taxed as ordinary income, which is true of nonqualified options but not (always) of stock. Although stock grants usually are taxed as ordinary income when they vest, executives can elect to pay tax earlier, so that subsequent appreciation is capital gain. After this "83(b) election," executives can hedge stock without any tax mismatch. ${ }^{58}$ Unlike option grants, then, stock grants sometimes can be hedged. This difference is all the more significant because stock grants have increasingly been replacing option grants in recent years. ${ }^{59}$ Not only is this tax effect becoming less important, but it also is at risk of being repealed. A range of tweaks in U.S. tax law could solve the executive's tax mismatch. ${ }^{60}$ Since the tax authorities never intended to block hedging, they are unlikely to notice (or care) if they inadvertently stop doing so.

\section{Accidental Byproducts}

Accidental effects can arise not only because tax and corporate governance have partially overlapping goals, but also because of wholly unrelated choices made by the tax system. This Section offers two examples, which derive from the tax system's reluctance to require difficult valuations.

\section{Venture Capital ("VC") and Valuation}

\footnotetext{
${ }^{57}$ If the capital loss can be used currently, but offsets long-term capital gain, it reduces tax only by $\$ 238,000$. (The tax rate is assumed here to be $23.8 \%$, which includes the $20 \%$ capital gains rate and the $3.8 \%$ net investment tax of Section 1411). As a result, the executive's tax bill still increases by $\$ 158,000$. In theory, the executive could respond by adjusting the size of the hedge so the two positions are offsetting on an after-tax, instead of a pre-tax, basis. But another anti-abuse rule, the straddle rules of Section 1092, prevents this impossible by subjecting hedging gains and losses to different rates. See Schizer, Executive and Hedging, supra note 3, at 481.

${ }_{58}^{5}$ Likewise, executives who received stock as investors (e.g., as founder of the company) also do not face this mismatch since their return also is taxed as capital gain. Also, once executives exercise their options, they can hedge the stock they receive. Yet they are also permitted to sell it, so hedging does not have the same agency costs implications, as long as it is disclosed.

${ }^{59}$ Emily Chasan, Last Gasp for Stock Options, WSJ.Com, Aug. 26, 2013, http://blogs.wsj.com/cfo/2013/08/26/lastgasp-for-stock-options/ "'At their peak in 1999, stock options accounted for about 78\% of the average executive's long-term incentive packages. Last year, they represented just $31 \%$, and are expected to shrink to $25 \%$ in the next two years, based on grant values so far this year ...."); James F. Reda, David M. Schmidt \& Kimberly A. Glass, The Move Away from Stock Options Continues: Preview of 2012 Data, J. Comp. \& Ben. 12, 14 (May / June 2013), http://www.jfreda.com/public/pdf/The\%20Move\%20Away\%20from\%20Stock\%20Options.pdf (estimating that in 2015 stock options will represent just $25 \%$ of the typical award).

${ }^{60}$ For a discussion, see Schizer, Executives and Hedging, supra note 3.
} 
The first involves venture-capital-financed startups. Although this chapter focuses on public companies, privately-owned high tech start-ups also struggle with agency costs. When these firms fail, investors cannot always tell whether the idea was unworkable or managers were not working.

Equity compensation is a standard response, which the tax system enhances (inadvertently) by applying capital gains rates. Although the U.S. tax system intentionally offers a preference for startups, ${ }^{61}$ the focus here is on an unintended preference that helps executives who receive stock in early VC funding rounds. This stock is effectively salary — issued for "sweat equity," not capital - which otherwise would be taxed at ordinary rates. Assume, for instance, that VCs pay $\$ 100$ per share for their stock, and the executive receives identical shares at the same time. Under the usual rules, the executive has $\$ 100$ of ordinary income upon receiving the stock and is eligible for capital gains rates only on subsequent appreciation. ${ }^{62}$ Nevertheless, executives prefer capital gains to ordinary income, and Silicon Valley has a strategy to provide it. The key is for VCs to receive convertible preferred stock ${ }^{63}$ so their shares are no longer the same as the executive's common shares. If the startup is liquidated, the VC is paid first. Although the value of this preference is unclear - since early stage startups typically have few assets ${ }^{64}$ — the standard practice is to treat the VC's preferred as much more valuable than the executive's common. When executives pay tax on the common, then, they assign a low valuation for it (e.g., one dollar, instead of the $\$ 100$ paid by the VC). When they sell later, proceeds above one dollar are reported as capital gain. ${ }^{65}$

The lynchpin of this strategy - aggressive valuation - has not been explicitly blessed by the U.S. government. Even so, valuation is difficult to challenge, especially when the relevant assets are ideas (which might not work), and not hard assets. Once again, the tax system makes a choice for its own reasons — in this case, administrability — that inadvertently reduces agency costs. The resulting subsidy piggybacks on the judgments of VCs. Since the strategy works only when outside investors provide funding, it is limited to startups that attract outside investors. ${ }^{66}$

\section{Untaxed Perquisites and Valuation}

\footnotetext{
${ }^{61}$ See Section 1202 (qualified small business stock).

${ }^{62}$ This assumes they make a Section 83(b) election. They also have the option of deferring the tax until the shares vest, but then all gain up to that point is taxed at ordinary rates. See Ronald J. Gilson \& David M. Schizer, Understanding Venture Capital Structure: A Tax Explanation for Convertible Preferred Securities, 116 HARV. L. REV. 874 (2003).

${ }^{63} \mathrm{Id}$.

${ }^{64}$ Indeed, there is an extensive literature debating why VCs in the U.S. always take convertible preferred, instead of common stock. Although signaling and other governance reasons are often invoked, tax is a central reason. Id.

${ }^{65}$ A cost of this favorable tax treatment is that the startup itself can deduct only one dollar per share instead of one hundred dollars. But early stage high tech startups often are not yet profitable, so they don't (yet) need the deduction. Id.

${ }^{66}$ Gilson \& Schizer, supra, note 62.
} 
Administrability also explains why the tax system does not tax some perquisites and thus inadvertently encourages them. It is hard to tax the utility managers derive from light hours, long lunches, lavish offices, and nepotistic hiring practices. Unfortunately, though, a manager may favor these benefits for a parallel reason: they are hard for shareholders to see. While tax is unlikely to motivate these practices, then, it may reinforce them. Unlike most issues in this chapter, this issue arises in all tax systems since the administrative cost challenge is universal.

Even so, different jurisdictions target work-related consumption in particular contexts. For example, U.S. firms can deduct only half of work-related entertainment expenses. ${ }^{67}$ Again, though, taxing the firm instead of the executive is a poor strategy. Managers who put their own interests ahead of the firm's worry less about a tax on the firm than one on them. Even a tax on managers will not have much effect, moreover, if it is too low. In the U.S., for example, executives are taxed on personal travel on corporate jets, but the tax is based on the taxpayerfriendly "standard industry fare level." The actual cost to the firm, then, significantly exceeds what the executive includes in income. ${ }^{68}$

Another tax strategy to constrain agency costs is to offer tax-free treatment only if a perquisite is available to all employees. Under these "nondiscrimination rules," executives can either offer the benefit broadly, which raises costs and can attract more attention, or pay tax on it. By raising a perquisite's visibility or imposing a tax on the executive, these rules discourage the proliferation of benefits, at least at the margin.

\section{Management Decisions About Capital Structure, Hedging, and Acquisitions}

Tax influences not only the pay executives receive, but also the choices they make. In a number of jurisdictions, for example, Pigouvian tax provisions discourage bribes and participation in international boycotts, while encouraging research and development, corporate charity, and various types of investments. ${ }^{69}$ In addition to these deliberate uses of tax, unintended effects also can be quite important. In the U.S., for instance, tax influences

\footnotetext{
${ }^{67}$ Section 274(n).

${ }^{68}$ The firm's deduction is limited to this amount so that, again, much of the tax cost is imposed on the firm, instead of the executive. See, e.g., Cleary Gottlieb Alert Memo, New Personal Use of Corporate Aircraft Tax Rules: Notes for Tax and Executive Compensation Practitioners (Aug. 22, 2012), http://www.cgsh.com/files/News/90795eb3eb05-43a8-9a3e-69ae66fcb5b6/Presentation/NewsAttachment/48406b2f-00b4-4baa-a0716c9f97bdcd30/CGSH\%20Alert\%20\%20New\%20Personal\%20Use\%20of\%20Corporate\%20Aircraft $\% 20$ Tax \%20Rules.pdf.

${ }^{69}$ See, e.g., Section 162(c); IRC Section 908; see also, e.g., Jeffrey P. Owens, Good Corporate Governance: The Tax Dimension, in TAX AND CORPORATE GOVERNANCE 11 (Wolfgang Schön ed. 2008) (all OECD members disallow deduction for bribery, and Germany, the U.K., and the U.S. all allow deductions for corporate charity).
} 
management decisions about capital structure, hedging, and acquisitions. This Part focuses on these (largely) unintended effects. ${ }^{70}$

\section{A. Capital Structure}

The U.S. tax system has two (largely) positive effects on capital structure, and one that is less clear. First, U.S. tax rules encourage leverage, which usually (but not always) reduces agency costs. Second, it discourages pyramidal ownership by taxing intercompany dividends. Third, the U.S. tax system can distort payout policies, although the magnitude and direction of this effect varies with the context and over time.

\section{Accidental Byproduct: Tax Advantages of Leverage}

The U.S. tax system favors leverage, and debt can reduce agency costs in three ways. First, debt ensures that some earnings are distributed as interest, leaving less for pet projects and perquisites. Second, the need to pay interest pressures managers to generate earnings. Third, bankruptcy can be even more costly for managers than shareholders. Senior executives are likely to lose their jobs and could have trouble finding another. This means debt - and thus the prospect of bankruptcy - can motivate managers to perform better. These factors could help explain why share prices usually rise when firms issue debt to buy back equity. ${ }^{71}$

Context is also important since debt sometimes can add to agency costs. Managers and shareholders often have different risk appetites, and debt can increase these differences in two (competing) ways. On one hand, managers of levered firms might shy away from especially risky investments, since bankruptcy is costlier for them than for shareholders. On the other hand, once managers believe bankruptcy is likely, they have the incentive take extra risk, even if it has negative expected value. ${ }^{72}$ Managers "swing for the fences" if anything short of a home run would not prevent bankruptcy and save their jobs. In contrast, creditors and shareholders would prefer more modest returns with higher expected value, which would increase their recoveries in bankruptcy.

Given these competing effects, the net impact of debt on agency costs varies with general market conditions, the maturity of the business, the sector, the assets backing the loan, ${ }^{73}$ and the

\footnotetext{
${ }^{70}$ In a frictionless world, capital structure does not affect firm value, as Modigliani and Miller famously showed, but the analysis obviously changes once we account for tax, information and transaction costs, and other frictions. See Franco Modigliana \& Merton H. Miller, The Cost of Capital, Corporation Finance and the Theory of Investment, 48 AM. ECON. REV. (1958).

${ }^{71}$ See, e.g., Kshitij Shah, The Nature of Information Conveyed by Pure Capital Structure Changes, 36 J. FIN. ECON. 89 (1994) (correlating exchange offers with information about reduced future cash flows for leveragedecreasing offers, and decreased risk for leverage increasing offers).

${ }^{72}$ Jensen \& Meckling, supra note 43 (managers take excessive risk since they benefit from gains but do not share in losses).

${ }^{73}$ Stewart C. Myers \& Nicholas S. Majluf, Corporate Financing and Investment Decisions When Firms Have Information That Investors Do Not Have, 13 J. FIN. ECON. 187 (1984) (firms with more tangible assets borrow
} 
negative externalities from insolvency. Bank failures, for example, are likely to pose greater systemic effects.

Just as debt usually (but not always) reduces agency costs, it also usually (but not always) has tax advantages. Unlike a dividend, interest is deductible in the U.S. ${ }^{74}$ This means profits paid to creditors are taxed only once (at the creditor level), while profits paid to shareholders are taxed twice. Although this difference persuaded Franco Modigliani and Merton Miller that firms should be capitalized with $100 \%$ debt, it is not quite so simple. ${ }^{75}$ The incentive to add debt is stronger when corporate tax rates are high. ${ }^{76}$ At the same time, this incentive is weaker when the firm already has enough debt to shelter its profits ${ }^{77}$ — or, for that matter, when it has other deductions to do so, such as depreciation, foreign tax credits, or stock option expenses. ${ }^{78}$ There also is a competing effect for multinationals. Though the relevant rules are technical, the upshot is that borrowing more can sometimes reduce a firm's foreign tax credits. ${ }^{79}$

more, since it is easier to grant security interest); James H. Scott, Jr. Bankruptcy, Secured Debt, and Optimal Capital Structure. 32 J. FIN. 1 (1977) (same).

${ }^{74}$ Section 163(a). Cf. Arne Friese, Simon Link \& Stefan Mayer, Taxation and Corporate Governance - The State of the Art, in TAX AND CORPORATE GOVERNANCE 392 (Wolfgang Schön ed. 2008) (noting that interest is $50 \%$ deductible in Germany).

${ }^{75}$ Franco Modigliani \& Merton H. Miller, Corporate Income Taxes and the Cost of Capital: A Correction, 53 AMER. ECON. REV. 433 (1963).

${ }^{76}$ Graham, supra note 5, at 1075 (the higher the corporate tax rate, the stronger this effect).

${ }^{77}$ E. Han Kim, Optimal Capital Structure in Miller's Equilibrium, in 2 FINANCIAL MARKETS AND INCOMPLETE INFORMATION: FRONTIERS OF MODERN FINANCIAL THEORY 36-48 (Sudipto

Bhattacharya \& George M. Constantinides, eds.1989) (if firm is already using enough debt to shield likely profits, there is no tax advantage in using more debt).

${ }^{78}$ Harry DeAngelo \& Ronald W. Masulis, Optimal Capital Structure Under Corporate and Personal Taxation, 8 J. FIN. ECON. 3 (1980) (noting that other sources of deductions can reduce tax advantage of debt); Dan Dhaliwal, Robert Trezevant \& Shiing-Wu Wang, Taxes, Investment-Related Tax Shields and Capital Structure, 14 J. AM. TAX'N. ASS'N. 1 (1992) (showing that firms with nondebt tax shield are less likely to use debt); John R. Graham, Mark H. Lang \& Douglas A. Shackelford, Employee Stock Options, Corporate Taxes, and Debt Policy, 59 J. FIN. 1585 (2004) (option deductions are large enough to reduce the median marginal tax rate for sample of large firms from 34\% to 26\%); Robert Trezevant, Debt Financing and Tax Status: Tests of the Substitution Effect and the Tax Exhaustion Hypothesis Using Firms' Responses to the Economic Recovery Tax Act of 1981, 47 J. FIN. 1557 (1992) (finding support for debt substitution and tax exhaustion hypotheses by examining 1981 legislation); Kathleen M. Kahle \& Kuldeep Shastri, Firm Performance, Capital Structure, and the Tax Benefits of Employee Stock Options, 40 J. FIN. AND QUAN. ANAL. 135 (2005) ("long- and short-term debt ratios are negatively related to the size of tax benefits from option exercise").

${ }^{79}$ In general, firms need foreign income in order to use foreign tax credits. Thus, if U.S. interest expense shelters foreign income, it can reduce the credits a firm can claim. There is a formula for deciding whether U.S. interest expense reduces overseas income, which is based on the percentage of assets abroad. The more assets held overseas, then, the more foreign tax credits a firm loses by taking on more U.S. debt. Empirical evidence shows that firms respond to this incentive. Julie H. Collins \& Douglas A. Shackelford, Foreign Tax Credit Limitations and Preferred Stock Issuances. 30 J. ACCT. RES. (Supp.), 103 (1992) (multinationals respond to 1986 change by using preferred stock instead of commercial paper); Kenneth A. Froot \& James R. Hines, Jr., Interest Allocation Rules, Financing Patterns, and the Operations of U.S. Multinationals, in THE EFFECTS OF TAXATION ON 
Moreover, if we look only at the tax treatment of the firm, but not the investor, we are missing half the picture. In the U.S., (taxable) investors are taxed less favorably on debt than on equity: interest is ordinary income, while dividends and capital gains are eligible for reduced rates. The importance of this offsetting disadvantage depends on who the creditor is, and also on the rate structure. ${ }^{80}$ If the creditor is tax exempt or foreign (and thus does not pay U.S. tax), this disadvantage is irrelevant. As a result, these clienteles are especially likely to hold debt. ${ }^{81}$ When they do, corporate cash flow funded by debt is, in effect, never taxed by the U.S. ${ }^{82}$ However, if the creditor is taxable, the tax advantage of debt over equity depends on how the corporate tax rate (which firms avoid by using debt) compares with the extra tax investors must pay. This additional tax is the spread between the tax on interest (at ordinary rates) and dividends (at capital gains rates). Under current rates, debt has a significant advantage.

Yet the magnitude of this advantage can change over time, since ordinary and capital gains rates for individuals fluctuate. When Congress changes these rates, it usually is not focused on managerial agency costs. The same is true when government tax experts modify the interest deduction. So although the tax treatment of debt has an important influence on agency costs, it is a blunt instrument.

\section{Pigouvian Effort to Discourage Pyramidal Ownership: Intercompany Dividends}

U.S. tax rules also reduce agency costs by discouraging "pyramidal ownership." As an example of a pyramid, assume A owns $10 \%$ of B (effectively controlling it), and B owns $10 \%$ of $\mathrm{C}$ (effectively controlling it). This means A effectively controls $\mathrm{C}$, even though it (indirectly)

MULTINATIONALS (Martin Feldstein, James R. Hines, Jr. \& R. Glenn Hubbard, eds.) (1995) (excess credit firms reduce their use of debt, with greater reductions in firms with more foreign assets); Rosanne Altshuler \& Jack M. Mintz, U.S. Interest-Allocation Rules: Effects and Policy, 2 INT'L. TAX AND PUB. FIN. 7 (1995) (multinationals with more assets abroad have more foreign debt, presumably because domestic interest would be allocated abroad). ${ }^{80}$ This disadvantage obviously grows as the gap widens between ordinary and capital gains rates. Graham, supra note 5, at 1082 (2003) ("If the investor-level tax on interest income $\left(\tau_{P}\right)$ is large relative to tax rates on corporate and equity income $\left(\tau_{C}\right.$ and $\left.\tau_{E}\right)$, the net tax advantage of debt can be zero or even negative."); Jeffrey K. MacKieMason, Do Taxes Affect Corporate Financing Decisions? 45 J. FIN. 1471 (1990) (finding that firms slightly increased use of debt after 1986 tax reform, which reduced tax rates on interest income).

81 It is not easy, though, to document this clientele effect empirically. See Graham, supra note 5, at 1096 (2003) ("The truth is that we know very little about the identity or tax status of the marginal investors ....").

${ }^{82}$ Not surprisingly, then, there is empirical evidence that share prices rise when firms announce they are replacing equity with debt. See, e.g., Ronald W. Masulis, Stock Repurchase by Tender Offer: An Analysis of the Causes of Common Stock Price Changes, 35 J. FIN. 305 (1980) (leverage-increasing exchange offers increase equity value by $7.6 \%$, and leverage-decreasing transactions decrease value by 5.4\%). Moreover, the exchange offers with the largest increases in tax deductions (debt-for-common and debt-for-preferred) have the largest positive stock price reactions.; Ellen Engel, Merle Erickson \& Edward Maydew, Debt-Equity Hybrid Securities, 37 J. ACCT. RES. 249 (1999) (comparing MIPS yields to preferred yields and concluding that the tax benefit of MIPS are approximately $\$ 0.28$ per dollar of face value, net of the aforementioned costs.); see also John R. Graham, Taxes and Corporate Finance in 2 HANDBOOK OF CORPORATE FINANCE: EMPIRICAL CORPORATE FINANCE 73 (B. Espen Eckbo ed. 2008). ("If all firms lever up to operate at the kink in their benefit functions, they could add $10.5 \%$ to firm value over the 1995-1999 period”). 
owns only $1 \%$. This sort of control, "assembled mainly with other people's money," can breed agency costs. $^{83}$

Yet although pyramids are the norm in many developed economies, ${ }^{84}$ they are much less common in the U.S. One reason is that the U.S. taxes intercompany dividends (i.e., a $7 \%$ tax on dividends received by firms owning between $20 \%$ and $80 \%$ of the dividend-paying firm), while many other jurisdictions do not (e.g., the EU, Japan, Australia, Switzerland, Singapore, and Canada). ${ }^{85}$ Commentators suggest that President Franklin Roosevelt proposed this tax in 1935 to address corporate governance problems with pyramids, ${ }^{86}$ although others claim that pyramids were already becoming uncommon in the U.S. for other reasons. ${ }^{87}$

\section{An Earnings Trap?}

Tax also can affect agency costs by influencing firm payout policies. In general, dividends mitigate agency costs by reducing the resources under management's control. When a project is funded with retained earnings instead of new debt or equity, managers are under less pressure to demonstrate the project's value, and thus are more likely to fund perquisites and pet projects. ${ }^{88}$ Paying dividends also is a signal of a firm's good health. ${ }^{89}$

As a result, if tax discourages dividends, it could exacerbate agency costs. But does the U.S. tax system actually discourage dividends? The answer is somewhat complex and contextspecific. By retaining earnings, a firm defers the shareholder's dividend tax, but this deferral does not necessarily reduce the shareholders' tax burden. Obviously, this deferral is irrelevant to

${ }^{83}$ See Randall Morck \& Bernard Yeung, Dividend Taxation and Corporate Governance, 19 J. ECON. PERSP. 163, 177 (2005).

${ }^{84}$ See Rafael La Porta, Florencio Lopez-de-Silanes \& Andrei Shleifer, Corporate Ownership Around the World, 54 J. FIN. 471 (1999).

${ }^{85}$ Morck \& Yeung, supra note 83 , at 176.

${ }^{86} \mathrm{Id}$.

${ }^{87}$ Steven A. Bank \& Brian R. Cheffins, The Corporate Pyramid Fable, University of Cambridge Faculty of Law Legal Studies Research Paper Series 11/04 (January 2011) ("The introduction of the intercorporate dividend tax did not foster a rapid dismantling of corporate pyramids. Instead, pyramidal arrangements were already rare in the U.S. . $\therefore$.").

${ }^{88}$ Michael C. Jensen, Agency Costs of Free Cash Flow, Corporate Finance, and Takeovers, 76 AM. ECON. REV. 323 (1986); Andrei Schleifer \& Robert W. Vishny, Management Entrenchment: The Case of Manager-Specific Investments, 25 J. FIN. ECON. 123, 123-24, 137 (1989) (retained earnings can fund irreversible investments that make firm less valuable but enhance management's value to firm); Nancy L. Rose \& Andrea Shepard, Firm Diversification and CEO Compensation: Managerial Ability or Executive Entrenchment, 28 RAND J. ECON. 489 (1997) (diversified firms are harder to manage and make skills more valuable).

${ }^{89}$ Sudipto Bhattacharya, Imperfect Information, Dividend Policy, and 'The Bird in the Hand' Fallacy, 10 BELL J. ECON. 259 (1979). As a result, empirical evidence suggests a connection between dividends and good governance. Larry H.P. Lang \& Robert H. Litzenberger, Dividend Announcements Cash Flow, Signaling vs. Free Cash Flow Hypothesis?, 24 J. FIN. ECON. 181 (1989) (dividend increases raise share prices the most for firms with ample cash flows and few investment opportunities); Rafael La Porta, Florencio Lopez-de-Silanes, Andrei Shleifer \& Robert W. Vishny, Agency Problems and Dividend Policies Around the World, 55 J. FIN. 1 (2000) (concluding that good governance causes higher dividends and that public investors demand dividends where free cash flow problems are worst). 
tax exempt shareholders. ${ }^{90}$ For less intuitive reasons, it may also not matter to taxable shareholders: if the firm reinvests these earnings at a profit, tax ultimately is levied on a larger base (the compounded earnings). ${ }^{91}$ Therefore, a taxable shareholder has the same after-tax return - whether the dividend is paid now or later — as long as two conditions are satisfied: first, the dividend tax has to be paid eventually (at the same tax rate); second, earnings must grow at the same (after-tax) rate either inside or outside the firm. ${ }^{92}$ When these conditions hold, there is no tax reason to retain earnings.

Yet the plausibility of these conditions can fluctuate over time, causing the U.S. tax system to discourage dividends in some circumstances while favoring them in others. For instance, the first condition - that the dividend tax is inevitable and constant - does not hold if earnings can be bailed out another way that avoids this tax. Share repurchases are a familiar example. ${ }^{93}$ For many years, they were taxed more favorably than dividends, ${ }^{94}$ and often replaced them in the 1990s. ${ }^{95}$ Like dividends, share repurchases can mitigate agency costs by reducing a

\footnotetext{
${ }^{90}$ It is hard to know how common tax-exempt shareholders are, but there is empirical evidence suggesting that taxable shareholders are the marginal holders. See, e.g., Edwin J. Elton, Martin J. Gruber \& Christopher R. Blake, Marginal Stockholder Tax Effects and Ex-Dividend-Day Price Behavior: Evidence from Taxable Versus Nontaxable Closed-End Funds, 87 REV. ECON. STAT. 579 (2005) (share values fall by after-tax value of dividend, not its full nominal value, on ex-dividend date); Trevor S. Harris, R. Glenn Hubbard \& Deen Kemsley, The Share Price Effects of Dividend Taxes and Tax Imputation Credits, J. PUB. ECON. 79 (2001) 569 (taxable individuals are marginal equity investors, so dividend taxes are impounded in price).

${ }^{91}$ Daniel Halperin, Will Integration Increase Efficiency? The Old and New View of Dividend Policy, 47 TAX L. REV. 645, 648 (1992) ("The advantage of deferral would be offset by the fact that the tax base would be growing as the corporation continued to accumulate earnings.").

${ }_{92} I d$. at 648 ("if all distributions were taxed at the same rate, the corporate and individual rates were the same and the rate of return inside the corporate sector is no different than the rate of return outside the corporate sector, the tax burden on corporate distributions could not be reduced by deferral of distributions."); see also, e.g., Alan J. Auerbach, Share Valuation and Corporate Equity Policy, 11 J. PUB. ECON. 291 (1979). For example, assume a firm has $\$ 100$ of earnings, which it either can distribute immediately or reinvest for three years. Assume also that this money can be invested - either inside or outside corporate solution - to earn the same $6.5 \%$ after-tax return. Assume also that it is subject to a shareholder level tax of $23.8 \%$ when it is distributed (the $20 \%$ capital gains rate plus the 3.8\% net investment tax). If the money is distributed now, the shareholder has $\$ 76.20$. After three years, this amount grows to $\$ 92.05$. Alternatively, if the firm invests the $\$ 100$, it grows to $\$ 120.80$ over three years and is distributed. After a $23.8 \%$ tax, the shareholder has the same $\$ 92.05$.

${ }^{93}$ Fisher Black, Dividend Puzzle, 2 J. PORTF. MAN. 215 (1976); Morck \& Yeung, supra, note 83, at 163, 168 (2005) ("Another option is for firms to make cash payments to shareholders by repurchasing their own shares").

${ }^{94}$ If structured properly, a share repurchase is taxed as capital gain. In contrast, dividends were taxed as ordinary income before 2003. See Graham, supra note 5, at 1105 (2003) ("All else being equal, tax effects imply that firm value is negatively related to 1 ) the portion of payout dedicated to dividends, and 2) dividend taxation relative to capital gains taxation."); see also Arne Friese, Simon Link \& Stefan Mayer, supra note 74, at 383 (noting an analogous effect in Germany and other imputation systems if the shareholder tax is higher than the corporate tax). ${ }^{95}$ Eugene F. Fama \& Kenneth R. French, Disappearing Dividends: Changing Firm Characteristics or Lower Propensity to Pay? 60 J. FIN. ECON. 3 (2001) (declining dividend yields in recent years); Morck \& Yeung, supra note 83 , at 171 (ordinary dividends remain roughly proportional to permanent component of corporate income, and extraordinary dividends or share repurchases are used to disburse free cash flow); $i d$ at 168 ("Since firms can make cash payments to their investors without dividends, and do so in ways that avoid dividend taxes, cutting dividend taxes may have less effect now than several decades ago."); Erik Lie \& Heidi J. Lie, The Role of Personal Taxes in Corporate Decisions: An Empirical Analysis of Share Repurchases and Dividends, J. FIN. \& Q. ANAL. 34, 533552 (1999) (firms with low-dividend payout (and presumably high-tax-rate investors) use self-tender-offer share
} 
firm's free cash flow. Yet if repurchases are more sporadic, so that scaling them back attracts less market attention, they impose somewhat less discipline on managers. In any event, the tax difference between repurchases and dividends was largely (but not entirely) eliminated in 2003. ${ }^{96}$ This sort of tax change, moreover, is another reason why dividend timing can matter. If dividend tax rates are expected to decline, there is a tax advantage in retaining earnings, so they can be distributed after the rate cut. Conversely, an expected rate increase is a reason to accelerate dividends.

The second condition - that earnings grow at the same after-tax rate whether they are reinvested or distributed - also does not always hold. If shareholders can earn a better return elsewhere, they will want a dividend. In making this judgment, shareholders should account for tax treatment, as well as pretax returns. For instance, a dividend can fund an investment in an LLC (which avoids corporate tax) or a foreign corporation (which is taxed at a lower corporate rate). In contrast, a shareholder may want to delay a dividend if reinvested earnings would compound at a favorable tax rate. For example, U.S. multinationals often do not want dividends from foreign subsidiaries, so these earnings can continue to earn tax-advantaged returns in lowtax jurisdictions. ${ }^{97}$ Obviously, these choices about retaining or distributing earnings can affect agency costs. For example, if foreign firms are harder for shareholders to monitor, a tax incentive to keep (or shift) capital there can compound agency costs. ${ }^{98}$

This analysis is sufficiently complex that unsophisticated shareholders may not fully understand it. If so, managers could invoke tax as a pretext not to pay dividends, even if it is not (and could not be) the real reason. Yet whether the facts actually support this claim - that is, whether tax actually discourages dividends — can vary across firms and over time. ${ }^{99}$ Indeed,

repurchases more often than they use special dividends, and these firms also use open-market repurchases more often than they increase regular dividends).

${ }^{96}$ Since 2003, dividends (like share repurchases) have been taxed at capital gains rates. But a difference still remains: Shareholders can use tax basis to reduce their tax on share repurchases, but not on dividends. For the firm itself, though, the tax burden is the same: deductions are not available for either dividends or share repurchases. See Section 162(k) (disallowing deduction for expenses associated with share repurchases).

${ }^{97}$ Alvin C. Warren, Jr., Deferral and Exemption of the Income of Foreign Subsidiaries: A Review of the Basic Analytics, Harv. Pub. Law Working Paper 14-18, at 9 (Jan. 2014),

http://papers.ssrn.com/sol3/papers.cfm?abstract_id=2390021, ("if the repatriation tax rate ... does not go down, the advantage of delaying repatriation of foreign earnings under current law comes not from delaying the repatriation tax, but from the application of a foreign tax rate ... on investment earnings during the period of deferral that is lower than the U.S. tax rate ... on such earnings").

${ }^{98}$ Cf. Mihir A. Desai, C. Fritz Foley \& James R. Hines, Jr., Dividend Policy Inside the Firm, NBER Working Paper 8698 (2002) (dividends of nonlisted foreign subs to U.S. parents typically are steady or rising, so that "dividend policies are largely driven by the need to control managers of foreign affiliates. Parent firms are more willing to incur tax penalties ... when their foreign affiliates are partially owned, located far from the United States, or in jurisdictions in which property rights are weak.”); C. Fritz Foley, Jay C. Hartzell, Sheridan Titman \& Garry Twite, Why Do Firms Hold So Much Cash? A Tax-Based Explanation, 86 J. FIN. ECON. 579-607 (2007).

${ }^{99} C f$. Roger Gordon \& Martin Dietz, Dividends and Taxes, in INSTITUTIONAL FOUNDATIONS OF PUBLIC FINANCE: ECONOMIC AND LEGAL PERSPECTIVES 220 (Alan J. Auerbach \& Daniel N. Shaviro eds. 2008) (concluding that signaling offers only a partial explanation for why firms pay dividends). 
during the Great Depression, an undistributed earnings tax was enacted to encourage dividends, but was soon repealed. ${ }^{100}$ Instead of this stick, the U.S. used a carrot in 2003, slashing the shareholder tax from $35 \%$ to $15 \%$. Dividends increased in response, ${ }^{101}$ especially where executives (or large taxable block-holders) owned relatively more stock . ${ }^{102}$ Correspondingly, just before this tax cut was supposed to expire, firms accelerated dividends — paying one-time "special" dividends and shifting January dividends into December — so the lower rate would still apply. ${ }^{103}$

\section{B. Hedging}

In addition to influencing payout policy in some cases, tax also can affect the decision of firms to hedge. Corporations often use derivatives to hedge currency, interest rates, commodity prices, and other sources of revenue or costs. The pervasiveness of hedging is something of a puzzle since diversified shareholders are already insulated from these fluctuations. For instance, while a spike in fuel prices is bad for airlines, it is good for oil companies. Because diversified shareholders hold both, firm-level hedging seems wasteful to them.

Yet managers may take a different view because they are less diversified. Hedging protects their human capital by keeping the firm out of bankruptcy. It also can smooth earnings, increasing earnings-based bonuses. While agency costs may explain some hedging, there are other explanations as well. For example, hedging can protect retained earnings so the firm does not depend as heavily on the capital markets, with their associated information and transaction costs.

In addition, tax supplies two additional reasons (or excuses) to hedge. First, hedging can increase a firm's debt capacity by reducing the likelihood of financial distress. ${ }^{104}$ This enables firms to take on more debt so they can shelter more profits with interest deductions. Second,

${ }^{100}$ See Mark J. Roe, STRONG MANAGERS, WEAK OWNERS: THE POLITICAL ROOTS OF AMERICAN CORPORATE FINANCE 118 (1994) ("The tax on undistributed profits threatened managers; within a few years the tax was dead.”); Bank, supra note 2, at 1204-06.

${ }^{101}$ Raj Chetty \& Emmanuel Saez, Dividend Taxes and Corporate Behavior: Evidence From the 2003 Dividend Tax Cut, 120 Q. J. ECON. 791, 828 (2005) ("The 2003 dividend tax cut induced a large set of firms to initiate regular dividend payments or raise the payments they were already making."); Brandon Julio \& David L. Ikenberry, Reappearing Dividends, 89 J. APP. CORP. FIN. (2004) (tax reduction is consistent with the reappearance of dividend-paying firms, although trend to initiate dividends was already in motion before tax cut was announced); Jennifer L. Blouin, Jana Smith Raedy \& Douglas A. Shackelford, The Initial Impact of the 2003 Reduction in the Dividend Tax Rate, University of North Carolina, Working Paper (2004) (tax cuts also led to special dividends).

${ }^{102}$ Chetty \& Saez, supra note 101, at 818-20, 23 (larger changes for firms with large taxable shareholder and bigger changes where senior executives have relatively more stock and fewer unexercised options; no change in dividends for firms where largest shareholder is not taxable).

${ }^{103}$ See Michelle Hanlon \& Jeffrey L. Hoopes, What Do Firms Do When Dividend Tax Rates Change?: An Examination of Alternative Payout Responses, J. FIN. ECON. (forthcoming) (estimating a \$7 billion increase in special dividends paid in the end of 2010 and 2012, as well as significant shifting of January dividends into December).

${ }^{104}$ Graham \& Rogers, supra note 10, at 815 (finding that hedging leads to greater debt usage, increases the debt ratio for the average firm by $3 \%$, and adds tax shields equal to $1.1 \%$ of firm value). 
hedging can smooth earnings, reducing the likelihood of net losses that firms cannot deduct. ${ }^{105}$ While the first reason arises only when debt-financed profits are tax-favored, as in the U.S., the second reason applies in any tax system that limits net losses.

\section{Acquisitions}

Tax also can motivate and shape acquisitions. In some cases, tax is a key reason for the deal. For instance, a U.S. firm may want to combine with a foreign firm in order to become a foreign firm for tax purposes, thereby reducing its tax bill. ${ }^{106}$ Even if tax is not the deciding factor, it is still likely to shape the deal's structure.

\section{Agency Cost Implications of Acquisitions: Entrenchment, Empire-Building, and Camouflage}

Affecting the probability or structure of an acquisition is important, since wise acquisitions can advance shareholder interests for familiar reasons. They transfer a business to new owners who value it more, for instance, because of synergies in production, better management, and the like. In addition, the possibility of being replaced in an acquisition can discipline management.

For parallel reasons, managers may resist being acquired. They want to preserve their jobs, as well as private benefits from controlling the target business, such as higher pay for managing a larger firm. Managers may also worry about becoming less diversified, as discussed above. Just as selling is unappealing to management, buying can be correspondingly appealing, since "empire building" offers diversification and private benefits of control. In addition, the complexity of acquisitions can enable managers to negotiate self-interested terms that are obscure enough to escape shareholder notice.

\section{Pigouvian Measures and Management Entrenchment: Parachutes and Greenmail}

\footnotetext{
105 John R. Graham \& Clifford W. Smith, Jr., Tax Incentives to Hedge, 54 J. FIN. 2241 (1999) ("From our analysis of more than 80,000 COMPUSTAT firm-year observations, we find that in approximately $50 \%$ of the cases, corporations face convex effective tax functions and thus have tax-based incentives to hedge."); Georges Dionne \& Martin Garand, Risk Management Determinants Affecting Firms' Values in the Gold Mining Industry: New Empirical Results. 79 ECONOMICS LETTERS 43 (2003)_(hedging among gold-mining firms is positively related to estimated convexity); Morton Pincus \& Shivaram Rajgopal, The Interaction between Accrual Management and Hedging: Evidence from Oil and Gas Firms, 77 ACCT. R. 127 (2002) (profitable oil and gas firms use derivatives to smooth income in response to tax incentives). But see Graham \& Rogers, supra note 10, at 815 (finding no evidence that firms hedge in response to tax function convexity).

${ }^{106}$ See infra Part IV.A.1.
} 
Since managers have self-interested reasons to resist being acquired, offering them special compensation in this scenario can reduce agency costs. As a result, Pigouvian taxes targeting golden parachutes are potentially counterproductive, as discussed above. ${ }^{107}$

Instead, it would be wiser to discourage the techniques managers use to resist acquisitions. In this spirit, the U.S. has a Pigouvian tax on "greenmail," or payments to potential acquirers for ceasing efforts to acquire a firm. The concern about greenmail is that managers are using the firm's money to save their jobs ${ }^{108}$ (although some defend the practice as a way of motivating outsiders to monitor management). ${ }^{109}$ To discourage greenmail, Section 5881 imposes a $50 \%$ tax on greenmail gains. But it is a very blunt instrument. In addition to taxing a premium received only by greenmailers, it also taxes general market appreciation. ${ }^{110}$

\section{Accidental Byproducts: Net Operating Losses and Lock-in as Reasons (or Excuses) for Management Entrenchment}

A change in control sometimes triggers tax costs that managers can invoke as a reason (or excuse) not to sell. For instance, when a firm has accumulated tax losses that it cannot use currently ("net operating losses" or "NOLs"), tax is a powerful reason not to be acquired. NOLs are a silver lining of losing money, since a firm can use them to avoid tax in later years. Indeed, profitable acquirers used to buy unprofitable targets in order to access their NOLs. However, to prevent this "loss trafficking," the U.S. enacted Section 382, which severely limits an acquirer's ability to use a target's tax losses. As a result, Section 382 offers firms with NOLs a compelling tax reason to avoid being acquired. Indeed, even an increase in a large shareholder's ownership stake can trigger draconian limits. In effect, NOLs become a poison pill of sorts, and also can prompt firms to adopt actual poison pills. ${ }^{111}$ The implications for agency costs are unfortunate. After all, a management team that has generated sizable NOLs usually should be replaced, not protected. Yet in seeking to defend the tax base, Section 382 inadvertently handed selfinterested managers an argument for keeping their jobs, while also complicating the task of

\footnotetext{
${ }^{107}$ See supra Part II.A.7.

${ }^{108}$ See John C. Coffee, Jr., Regulating the Market for Corporate Control: A Critical Assessment of the Tender Offer's Role in Corporate Governance, 84 COLUM. L. REV. 1145, 1293 (1984); Jeffrey N. Gordon \& Lewis A. Kornhauser, Takeover Defense Tactics: A Comment on Two Models, 96 YALE L. J. 295, 297 (1986-87) ("[T]arget stock buybacks are unlikely to increase shareholder wealth as a general matter and, on a shareholder wealth criterion, should not be permitted").

${ }^{109}$ Jonathan R. Macey \& Fred S. McChesney, A Theoretical Analysis of Corporate Greenmail, 95 YALE L. J. 13, 15 (1985) ("greenmail payments can be an efficient means of compensating those who supply valuable information to the market (or the firm) about the value of a firm's stock").

${ }^{110}$ For a critique, see generally Edward A. Zelinsky, Greenmail, Golden Parachutes and the Internal Revenue Code: A Tax Policy Critique of Sections 280G, 4999 and 5881, 35 VILL. L. REV. 131, 166-68 (1990) (fails to distinguish between good and bad greenmailing).

${ }^{111}$ Mark C. Van Deusen, A Primer on Protecting Tax Losses from a Section 382 Ownership Change, William \& Mary Annual Tax Conference, Paper 20, at 18 (2010), http://scholarship.law.wm.edu/tax/20 ("Many public companies with significant NOLs and NCLs have recently adopted poison pill plans that are intended to discourage an ownership change. In 2009, over 40 public companies adopted section 382 poison pills, including Citigroup Inc. and Ford Motor Company.").
} 
reviving struggling companies. ${ }^{112}$ In approving NOL pills, moreover, Delaware courts have emboldened managers to implement other aggressive takeover defenses; NOL pills have especially low triggers — taking effect when a would-be-acquirer has acquired only $4.99 \%$ of the target — and are invoked to justify other low-trigger pills. ${ }^{113}$

In resisting a change of control, self-interested managers also can emphasize the tax bill that would come due. Unsophisticated observers might not realize that this tax problem could be solvable, for instance, with a "tax-free" reorganization (which defers the seller's tax) or a larger deal premium to offset the seller's tax. Again, the tax system's goal here is not to protect management. The relevant tax rule - the so-called "realization rule," which defers gain or loss until the asset is sold - is supposed to make the tax system more administrable, not to influence agency costs. At the same time, rules that allow "tax-free" acquisitions have governance advantages in facilitating a more vibrant market for corporate control. ${ }^{114}$

\section{Accidental Byproducts: Depreciation, Tax Holidays, and Avoiding Net Losses as Reasons (or Excuses) for Empire-Building}

Managers can invoke tax not only as an obstacle to selling, but also as a justification for buying. Like many tax effects in this chapter, the tax advantages of acquisitions come and go. Before the 1986 tax reform, newly-purchased assets offered very generous depreciation in the U.S., so the tax advantage to purchasers could outweigh the tax cost to sellers. ${ }^{115}$ Yet this tax advantage was eliminated when the 1986 act raised corporate capital gains rates (increasing the tax cost to sellers) and lowered corporate ordinary rates (reducing the tax benefit to buyers). ${ }^{116}$

\footnotetext{
${ }^{112}$ Samuel J. Dimon, Limit My Practice Instead! Thoughts on Reforming Section 382, TAXES-THE TAX MAGAZINE 65 (March 2010) ("Code Sec. 382 influences corporate decision-making more than it should. Stressed companies too often are inhibited by fear that otherwise rational economic decisions will precipitate an ownership change (or set up conditions where an ownership change could easily occur). As a consequence, stock-for-debt exchanges outside of bankruptcy may be avoided, or pared back, and so may stock offerings to raise needed cash").

${ }^{113}$ Versant, Enters. v. Selectica, Inc., 5 A.3d 586 (Del Sup. Ct. 2010) (approving NOL pill with $4.99 \%$ trigger); Paul H. Edelman and Randall S. Thomas, Selectica Resets the Trigger on the Poison Pill: Where Should the Delaware Courts Go Next? 87 IND. L. REV. 1087, 1090 n. 27 (2012) ("Law firms are already claiming that Selectica validates 'acting in concert' poison pills with $4.99 \%$ triggers, which are designed to stop shareholders from engaging in coordinated activities").

${ }^{114}$ Friese, Link \& Mayer, supra note 74.

${ }^{115}$ See Ronald J. Gilson, Myron S. Scholes \& Mark A. Wolfson, Taxation and the Dynamics of Corporate Control: The Uncertain Case for Tax-Motivated Acquisitions, in KNIGHTS, RAIDERS, AND TARGETS: THE IMPACT OF THE HOSTILE TAKOVER (John C. Coffee, Jr., Louis Lowenstein \& Susan Rose-Ackerman, eds. 1988) (describing this pre-86 strategy); Carla Hayn, Tax Attributes as Determinants of Shareholder Gains in Corporate Acquisitions23 J.FIN. ECON. 121 (1989) (finding that target shareholder capital gains and tax benefit of stepped up basis affect returns of bidder and target after taxable acquisition is announced in pre-86 transactions).

${ }^{116}$ Before 1986, corporate capital gains were taxed at $28 \%$, while the maximum rate for ordinary income was $46 \%$. Since 1986, the top rate for both has been 35\%. See also Myron S. Scholes \& Mark A. Wolfson, The Effects of Changes in Tax Laws on Corporate Reorganization Activity, 63 J. BUS. S141 (1990).
} 
Even so, the pendulum swung back (to an extent) after 1993 when the U.S. enacted more generous depreciation for good will and other intangibles purchased in acquisitions. ${ }^{117}$

Likewise, the U.S. offered a temporary tax cut in 2004 when U.S. multinationals received dividends from foreign subsidiaries. To claim this "tax holiday," U.S. firms had to invest the money instead of paying dividends or buying back their shares. As a result, many used this cash for acquisitions. ${ }^{118}$

There also is a more enduring tax justification for empire-building. A firm with diversified businesses is less likely to have net losses, which cannot be deducted (currently). ${ }^{119}$ This advantage flows from a pervasive feature of tax systems that is unlikely to change: taxpayers usually need income to use tax losses. This tax advantage of diversification can reinforce (or rationalize) a manager's personal desire for diversification (discussed above).

\section{Accidental Side Effects: Complexity as Camouflage}

Agency costs arise not only in deciding whether to do an acquisition, but also how to do it. Various acquisition structures offer different tax consequences, ${ }^{120}$ and faithful agents choose the structure that best serves shareholder interests. For example, U.S. buyers are likely to prefer a taxable deal, which gives them a higher tax basis and thus more depreciation. In contrast, U.S. sellers usually favor "tax-free" deals that defer their tax. To resolve this conflict, the parties should choose the structure that minimizes their combined tax liabilities (and advances their business objectives). ${ }^{121}$ They can then share the resulting tax savings by adjusting the purchase price. ${ }^{122}$ In this way, managers can maximize the after-tax returns of shareholders. ${ }^{123}$

\footnotetext{
${ }^{117}$ Section 197; see also Steven L. Henning \& Wayne H. Shaw, The Effect of the Tax Deductibility of Goodwill on Purchase Price Allocations, 22 J. AMER. TAX'N ASSN. 18 (2000) (finding that enactment of Section 197 increased purchase price, as buyers shared tax savings with sellers); Connie D. Weaver, Divestiture Structure and Tax Attributes: Evidence from the Omnibus Budget Reconciliation Act of 1993. 22 J. AMER. TAX'N. ASSN. (SUPP.) 54 (2000) (enactment of Section 197, which introduced deduction for goodwill, increased the probability of the taxable transaction being structured to obtain a step-up in basis and thus a deduction for goodwill; step-up is more likely when acquiring firm has higher marginal tax rate); Benjamin C. Ayers, Craig E. Lefanowicz \& John R. Robinson, The Effects of Goodwill Tax Deductions on the Market for Corporate Acquisitions, 22 J. AMER. TAX'N ASSN. 34 (SUPP.) (2000) (enactment of 197 did not increase frequency of taxable transactions with basis step up, but did increase purchase price premium, so that target gets $75 \%$ of tax benefit).

118 Thomas J. Brennan, Where the Money Really Went: A New Understanding of the AJCA Tax Holiday (March 6, 2014). Northwestern Law \& Econ Research Paper No. 13-35. Available at SSRN: http://ssrn.com/abstract=2312721 or http://dx.doi.org/10.2139/ssrn.2312721.

119 See, e.g., Randall Morck, Andrei Shleifer, \& Robert W. Vishny, Do Managerial Objectives Drive Bad Acquisitions?, 45 J. FIN. 31, 31-32 (1990) .

${ }^{120}$ See generally Martin Ginsburg \& Jack S. Levin, eds., MERGERS, ACQUISITIONS \& LEVERAGED BUYOUTS, Chicago, Illinois: Commerce Clearing House (1989).

${ }^{121}$ Gilson, Scholes \& Wolfson, supra note 115.

${ }^{122}$ Merle Erickson \& Shiing-wu Wang, The Effect of Transaction Structure on Price: Evidence from Subsidiary Sales, 30 J. ACCT. \& ECON. 59 (2000) (finding that when one firm buys another's sub, price depends on the seller's tax on gain); Benjamin C. Ayers, Craig E. Lefanowicz \& John R. Robinson, Shareholder Taxes in Acquisition Premiums: The Effect of Capital Gains Taxation, 58 J. FIN. 2783 (2003) (finding that premium paid in taxable acquisitions increases with the capital gains taxes of the target shareholders).
} 
Like in other responsibilities, though, managers are not always faithful agents in tax planning. Self-interested tax structuring is especially hard for shareholders to monitor, since tax rules are so esoteric. For example, assume managers have self-interested reasons to buy another company. To clinch the deal, they might accommodate the seller's desire for a tax-free structure, even if a taxable deal is more tax-efficient. This is a form of overpaying, but one that is well hidden from shareholders, who are unlikely to notice the firm's lost depreciation deductions. Alternatively, instead of neglecting the firm's tax position, managers can overemphasize their own taxes. For instance, in selling the company, managers may seek to minimize their own tax bills as selling shareholders. ${ }^{124}$ They might accept a reduced sale price in return for a "tax-free" structure, even though tax exempt and foreign shareholders (who do not owe U.S. tax anyway) would prefer a higher price. Managers who prioritize their own tax bills in this way are effectively taking money from these shareholders, but in a way that is hard to see.

Discerning the true motivation of managers is all the more difficult because deal structuring — such as the use of cash or stock as the acquisition currency - can be explained in other ways. For example, cash deals usually close more quickly and involve fewer hurdles than stock deals. ${ }^{125}$ In addition, when an acquirer offers its own stock instead of cash, it may be signaling that its stock is overvalued. ${ }^{126}$ Because there are competing considerations, it can be all the more difficult for shareholders to know if managers are making a value-maximizing structuring choice or a self-interested one. ${ }^{127}$ To my knowledge, this influence of tax on corporate governance - tax structuring that camouflages self-interested deal terms - is new to the academic literature.

\section{Tax and Monitoring: Who is Watching Management?}

Although shareholders can reduce agency costs by monitoring management, individual shareholders may not have enough at stake to do so. Their legal ability and economic incentive

\footnotetext{
${ }^{123}$ See, e.g., Edward L. Maydew, Katherine Schipper, \& Linda Vincent. The Impact of Taxes on the Choice of Divestiture Method, 28 J. ACCT. \& ECON. 117 (1999) (finding that the size of the tax differential between divestiture methods affects the form of divestiture; firms with the largest potential tax benefits from using a spin-off opt for spin-offs); William M. Gentry \& David M. Schizer, Frictions and Tax-Motivated Hedging: An Empirical Exploration of Publicly-Traded Exchangeable Securities, 56 NAT'L. TAX J. 167 (2003) (empirical study of use of contingent notes to simulate economics of sale without triggering tax).

${ }^{124}$ The assumption here is they received shares as equity compensation and made an 83(b) election, so they are eligible for "tax-free" treatment in selling these shares.

${ }^{125}$ See Isfandiyar Shaheen, Stock Market Reaction to Acquisition Announcements using an Event Study Approach, 2006, https://dspace.fandm.edu/bitstream/handle/11016/4167/Shaheen.pdf?sequence=1.

${ }^{126}$ Myers \& Majluf, supra note 73, at 187.

127 The market may well react to structuring choices; indeed, there is a literature showing that cash deals generate a more favorable market reaction than stock deals. See, e.g., Nickolaos G. Travlos, Corporate Takeover Bids, Means of Payment, and Bidding Firms' Stock Returns, 42 J. FIN. 943 (1987) (cash bids generate more favorable market reaction for bidder than stock bids); Shaheen, supra note 125 (cash bids generate more favorable market reaction for both target and bidder). But in explaining this difference, commentators focuses on signaling and the likelihood that the deal closes, and not on the tax difference in these structures or the possibility that managers are allocating tax costs as a less visible means of under- or over-paying. If sophisticated commentators do not focus on these issues, unsophisticated shareholders also are unlikely to do so.
} 
to monitor can be influenced by the tax system, at least to a degree. While some of these effects are intended, most are not. The tax system not only can encourage (or discourage) shareholder monitoring, but also can substitute for it (at least to a degree). After all, the government has its own revenue-related reasons to monitor management. Even so, this is a mixed blessing for shareholders.

\section{A. Shareholder Monitoring}

\section{Accidental Byproduct: Inversions and Jurisdiction}

Tax has perhaps the greatest impact on shareholder monitoring in influencing where a firm incorporates and, thus, what corporate law protections shareholders have. Under U.S. tax rules, incorporating outside the U.S. offers a notable advantage: avoiding U.S. tax on overseas earnings. Although a Delaware firm owes U.S. tax on profits earned abroad, a Cayman Islands firm does not. Yet this tax savings can come at a cost. Other jurisdictions may not offer comparable shareholder protections, especially tax havens like the Cayman Islands or Bermuda. ${ }^{128}$ This means U.S. tax rules offer a reason (or excuse) to incorporate in jurisdictions with weaker legal constraints on managerial agency costs.

A straightforward response to this tax incentive is to incorporate overseas when starting a business. Still, this practice is relatively rare. ${ }^{129}$ It is cheaper and easier to organize in the U.S. Founders also are sometimes unsophisticated about tax planning or are unsure how much nonU.S. profit they will earn. In addition, key investors may want U.S. corporate law protections.

Even so, a U.S. firm can become a non-U.S. firm later. In a so-called "inversion," the U.S. entity that has been the multinational's parent becomes a subsidiary of a new non-U.S. parent. ${ }^{130}$ Yet after a number of high profile inversions in the late 1990 s and early $2000 \mathrm{~s},{ }^{131}$ Congress responded with Section 7874, which taxes the new non-U.S. parent as a U.S. firm.

\footnotetext{
${ }^{128}$ Victor Fleischer, Despite Tax Rules, Companies Stick With U.S., N.Y. TIMES, June 6, 2013 ("Minority investors might be nervous about enforcing their contractual and shareholder rights in a court in Bermuda, British Virgin Islands or Ireland"), http://dealbook.nytimes.com/2013/06/06/despite-tax-rules-companies-stick-with-u$\mathbf{s} /$ ? $\mathbf{p h p}=$ true\& type=blogs\& $\mathbf{r}=\mathbf{0}$.

${ }^{129}$ Susan C. Morse, Startup Ltd: Tax Planning and Initial Incorporation Location, 14 FLA. TAX. REV. 319,320 (2013) (arguing that "startup firms generally organize as US corporations" because of "limited tax benefits of nonUS incorporation, legal benefits of US incorporation, startups' liquidity and other resource constraints, and investor preferences"); Eric J. Allen \& Susan C. Morse, Tax Haven Incorporation for U.S.-Headquartered Firms: No Exodus Yet, 66 NAT. TAX. J. 395 (2013) (finding that U.S.-headquartered MNCs rarely have incorporated parent corporations in tax-haven jurisdictions; only 27 firms, or about three percent, of the 918 U.S.-headquartered MNCs identified in their sample of IPOs have incorporated in tax havens).

${ }^{130}$ Desai \& Hines, supra note 11, at 410 ("These national differences create opportunities for American companies with foreign income to reduce their tax obligations by expatriating, thereby shedding their American identities and becoming foreign corporations").

${ }^{131}$ Donald J. Marples \& Jane C. Gravelle, Congressional Research Services Report 7-5700: Corporate Expatriations, Inversions, and Mergers: Tax Issues, May 27, 2014, 4, http://fas.org/sgp/crs/misc/R43568.pdf ("Among the more high-profile inversions were Ingersoll-Rand, Tyco, the PXRE Group, Foster Wheeler, Nabors Industries, and Coopers Industries").
} 
Although this rule shut down this "first wave" of inversions, ${ }^{132}$ it does not reach a firm that has substantial business operations in its new sites of incorporation. ${ }^{133}$ In addition, the rule does not apply when a U.S. firm combines with a sufficiently large non-U.S. firm. For this combined entity to avoid being taxed as a U.S. firm, the former shareholders of the U.S. firm must own less than $80 \%$ of it. Using this rule, a wave of U.S. pharmaceutical companies have bought smaller foreign firms to become Irish, British, Dutch, or Swiss companies. ${ }^{134}$ In these deals, shareholder protections can change, depending upon where the new firm is incorporated and what its new charter provides. ${ }^{135}$

While the goal of these tax rules is to have a broader tax base - not to influence corporate governance - the tax system can respond to inversions in various ways, each of which has agency cost implications. One possibility is to make the tax benefits from inversions harder to claim. If this goal is pursued successfully, the incentives to reincorporate overseas (and the associated governance risks) are diminished. Another approach is to stop using the site of incorporation to define tax residence. In the U.K. and Canada, for instance, tax residence does not turn on where the firm is incorporated, but on where it is managed. Under this approach, if senior management stays in the U.S., there is no U.S. tax advantage to incorporating in the Cayman Islands. Finally, instead of trying harder to tax worldwide earnings, the U.S. can stop trying. Most developed economies have territorial systems, which tax firms only on domestic earnings, not on foreign earnings. If the U.S. adopts a territorial system, Delaware firms - like Cayman Islands or Irish firms - would not owe U.S. tax on overseas profits. There would no longer be a tax reason to leave Delaware.

\section{Accidental Byproduct: Choice of Entity}

In the U.S., tax and governance are in tension in deciding not only where to incorporate, but also what entity to use. A partnership or LLC has a familiar tax advantage over a corporation: shareholders are taxed, but the entity is not. ${ }^{136}$ Under current law, the maximum

\footnotetext{
${ }^{132}$ See generally Jefferson P. Vanderwolk, Inversions under Section 7874 of the Internal Revenue Code: Flawed Legislation, Flawed Guidance, 30 NW. J. INT'L. L. \& BUS. 699, 700 (2010) ("Section 7874 is widely believed to have had a severe chilling effect on inversions of publicly held corporations").

${ }^{133}$ To make it more difficult to avoid the statute by doing business in the new site of incorporation, the U.S. Treasury increased the safe harbor for substantial business activities from $10 \%$ to $25 \%$. This more demanding test makes it less likely this path will be used. Marples \& Gravelle, supra note 131, at 6.

${ }^{134}$ Doug Gelles \& Chad Bray, Drug Firms Make Haste to Elude Tax, N.Y. TIMES, July 14, 2014, http://dealbook.nytimes.com/2014/07/14/shire-and-abbvie-in-talks-over-53-billion-pharmaceutical-

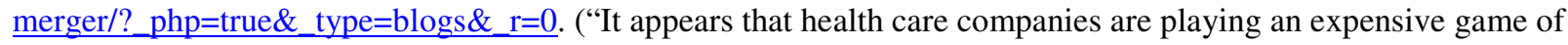
keeping up with the Joneses").

${ }^{135}$ See Orsolya Kun, Corporate Inversions: The Interplay of Tax, Corporate, and Economic Implications, 29 DEL. J. CORP. L. 313 (2004) (noting that fiduciary duties of managers can be different, and that courts are likely to have less corporate law experience and fewer reported precedents).

${ }^{136}$ A further tax advantage of LLCs is that they allow losses to flow through to investors, so that net operating losses are not trapped inside a failed firm. Cf. Joseph Bankman, The Structure of Silicon Valley Start-Ups, 41 UCLA L. REV. 1737, 1738 (1994) (noting that Silicon Valley startups are usually C-corporations instead of pass-through entities, and that this structure is potentially tax-inefficient).
} 
U.S. rate for a pass-through entity is $43.4 \%$, compared with a combined $51.5 \%$ rate for a corporation. ${ }^{137}$ Yet this tax advantage has a governance price, although probably a lower one than inversions: pass-through entities can have weaker investor protections because corporate default rules do not automatically apply. This difference should not be overstated, since these protections can be added to the charter. ${ }^{138}$ In addition, investors in a pass-through may not need as much legal protection. Because pass-through treatment is not available for public corporations, ${ }^{139}$ there are fewer shareholders, so monitoring is more feasible.

\section{Pigouvian and Unintended Incentives for Long-Term Ownership: Reduced Capital Gains Rates and Lock-in}

Tax can affect monitoring also by encouraging long-term investment. To claim the U.S. capital gains preference, for example, investors must hold for at least a year. Yet this preference is an imperfect vehicle for enhancing monitoring. After all, monitoring is effective only if shareholders can influence management, something that is more plausible for large shareholders than small ones.

The analysis is similar for other ways the tax system (inadvertently) encourages longterm holding. The realization rule, in deferring tax until stock is sold, can reduce the present value of tax for those who keep it longer. ${ }^{140}$ In the U.S., the step up in basis at death also discourages sales, since those who die with stock avoid income tax on appreciation. ${ }^{141}$ Once again, however, the incentive to hold longer may not translate into better monitoring. In addition, there is no longer an incentive to hold when a tax-free exit is available, for instance, through hedging or a tax-free reorganization. ${ }^{142}$ The same is true if stock prices decline; the incentive then is to sell in order to trigger tax losses. ${ }^{143}$

\footnotetext{
${ }^{137}$ A dollar of corporate profit is taxed at $35 \%$ at the corporate level and then at $23.8 \%$ at the shareholder level (a $20 \%$ capital gains tax plus the $3.8 \%$ net investment income tax $)$. This leaves only 49.5 cents: $1(1-.35)(1-.238)=$ .495. In contrast, a dollar taxed once at the maximum individual rate of 39.6 (plus the $3.8 \%$ net investment income tax, assuming it applies) leaves 56.6 cents.

${ }^{138}$ For instance, although Delaware LLCs impose fiduciary duties, the case law is considerably less developed than Delaware corporations. Cf. Victor Fleischer, The Rational Exuberance of Structuring Venture Capital Start-Ups, 57 TAX L. REV. 137 (2003-04). (why nontax business considerations often lead firms to organize as corporations instead of as partnerships). A business that wants both Delaware corporate law and pass-through treatment can use an S-Corporation. Yet S-Corporations are subject to various limits that do not apply to LLCs.

${ }^{139}$ Michael Doran, Managers, Shareholders, and the Corporate Double Tax, 95 VA. L. REV. 519, 528 (2009) ("Whether it makes policy sense or not, the corporate double tax serves as a toll charge imposed by the government on accessing capital through the securities markets").

${ }^{140}$ Schizer, Realization as Subsidy, supra note 6, at 1551-52.

${ }^{141}$ As James Repetti has observed, though, this rule can have adverse corporate governance effects by favoring retained earnings over distributions. James R. Repetti, The Misuse of Tax Incentives to Align ManagementShareholder Interests, 19 CARDOZO L. REV. 697, 716-17 (1997).

${ }^{142}$ David M. Schizer, Frictions as a Constraint on Tax Planning, 101 COLUM. L. REV. 1312 (2001). As noted above, "tax-free" reorganizations can reduce agency costs by enlivening the market for corporate control. See supra Part III.C.3.

${ }^{143}$ The price pressure from selling may have positive corporate governance effects but not through monitoring.
} 
All these effects depend on tax details that vary over time and across jurisdictions. For example, tax effects reduced the concentration of share ownership in both the U.K. and Germany, but for different reasons. In the U.K., estate taxes forced families to sell. ${ }^{144}$ Germany, by contrast, was deliberately pursuing a corporate governance agenda, introducing an exemption from the corporate capital gains tax so banks and insurance companies would sell their crossholdings. ${ }^{145}$

\section{Accidental Byproduct: Tax Exempts, Institutional Investors, and Boards as Monitors}

These lock-in effects obviously do not affect tax-exempt shareholders who have no tax liability to defer. In theory, this freedom from tax affords them extra resources for monitoring, as Randall Mork and Bernard Yeung have argued. Yet tax exempts still have the same reason as taxable shareholders not to monitor: they bear the full cost while reaping only part of the benefit.

U.S. tax rules can also influence monitoring by institutional investors. On one hand, individual investors secure favorable tax treatment by investing in tax deferred accounts; these often (though not always) are invested with an institution, which has more resources for monitoring than an individual investor. ${ }^{146}$ On the other hand, U.S. tax rules keep mutual funds from concentrating on a small number of companies, even though this strategy would be more conducive to monitoring. ${ }^{147}$ Analogous diversification requirements apply to real estate holding companies (so-called "REITS"), ${ }^{148}$ annuities, and segregated accounts. ${ }^{149}$ The significance of these rules should not be overstated, though; institutional investors vary in their willingness to monitor, while the value of their monitoring is debated.

Tax rules can also weaken monitoring by the board. In Germany, director compensation is only partially deductible (as a way to keep it from serving as disguised, and thus untaxed, dividends). According to Wolfgang Schön, this rule discourages firms "from hiring and paying high-class people" for the board, ${ }^{150}$ although some firms avoid the constraint by also hiring directors as consultants. ${ }^{151}$

\section{B. Shared Interests: Government Monitoring}

\footnotetext{
${ }^{144}$ Steven Bank \& Brian R. Cheffins, Tax and the Separation of Ownership and Control, in TAX AND CORPORATE GOVERNANCE 111 (Wolfgang Schön ed. 2008).

${ }^{145}$ Courtney H. Edwards, Mark H. Lang, Edward L. Maydew \& Douglas A. Shackelford, Germany's Repeal of the Corporate Capital Gains Tax: The Equity Market Response, 26 JATA 73 (Supp. 2004); Friese, Link \& Mayer, supra note 74, at 375 (describing exemption as an effort "to unravel the close net of cross-holdings" in Germany). ${ }_{146}$ Andrei Shleifer \& Robert W. Vishny, Large Shareholders and Corporate Control, 94 J. POL. ECON. 461 (1986) (Tax on dividends gives investors an incentive to hold stock through tax exempt organizations).

${ }^{147}$ To qualify for pass-through tax treatment, a mutual fund (or so-called "RIC") cannot hold more than $25 \%$ of its portfolio in a single company. Section $851(\mathrm{~b})(3)$.

148 Section 857.

149 Treas. Reg. 1. 817-5(b).

${ }^{150}$ Schön, supra note 8, at 60.

${ }^{151}$ Friese, Link \& Mayer, supra note 74, at 392.
} 
In addition, the tax system has its own revenue-related reasons to verify a firm's profits, which sometimes have spillover benefits for shareholders. ${ }^{152}$ After all, managers who cheat the government might be willing to steal from (or mislead) shareholders as well. ${ }^{153}$ Both types of strategies use similar techniques, such as offshore accounts and off-balance sheet entities. As a result, rules protecting the fisc can (inadvertently) protect shareholders as well, as Mihir Desai and Dhammika Dharmapala have emphasized. ${ }^{154}$ For example, when the Russian government began cracking down on offshore entities, the Russian stock market reacted favorably. ${ }^{155}$ The (bizarre) implication is that managers were stealing more than the Russian government was seeking in taxes.

These spillover benefits are more obvious when book and tax accounting are conformed. ${ }^{156}$ In these circumstances, when the tax system demands greater transparency, shareholders receive more informative financial statements. Yet the opposite can be true as well. If book-tax conformity induces firms to report less accurately (e.g., understating profits to minimize taxes), shareholders end up with less reliable information. ${ }^{157}$

Even without book-tax conformity, tax enforcement can generate useful information for shareholders in two ways. First, if returns are publicly available — as was briefly true when the U.S. corporate tax was first enacted - they are an independent source of information; indeed, transparency was an early justification for the U.S. corporate tax. ${ }^{158}$ Second, even if returns are confidential, managers who have to track information for tax reasons (e.g., on corporate campaign contributions) cannot invoke administrative costs as a reason to withhold it from shareholders.

Needless to say, though, government and shareholder interests are only partially aligned. To shareholders, lowering the tax bill is likely to enhance returns ${ }^{159}$ and raise stock prices. ${ }^{160}$ As

\footnotetext{
${ }^{152}$ Mihir A. Desai, Alexander Dyck \& Luigi Zingales, Theft and Taxes, 84 J. FIN. ECON. 591 (2007).

${ }^{153}$ Michelle Hanlon \& Joel Slemrod, What Does Tax Aggressiveness Signal? Evidence from Stock Price Reactions to News About Tax Shelter Involvement, 93 J. PUB. ECON. 126, 128 (2009) (aggressive tax planning "may signal that the dishonesty extends to the financial accounting statements").

${ }^{154}$ Desai \& Dharmapala, supra note 8 , at $17-18$.

${ }^{155}$ Desai, Dyck \& Zingales, supra note 152.

${ }^{156}$ In Germany, tax and financial accounting generally are aligned, whereas in the U.S., tax and financial accounting can diverge in significant ways. See Friese, Link \& Mayer, supra note 74, at 376-78, 380-81 (discussing corporate governance advantages and disadvantages of book-tax conformity).

${ }^{157}$ See. Hanlon, Maydew, \& Terry Shevlin, supra note 12(finding that quality of information to shareholders declined as a result of change in tax law requiring greater book-tax conformity, which induced firms to report more conservatively).

${ }^{158}$ Kornhauser, supra note 7, at 134-35 ("publicity" was important early rationale for corporate tax; as first enacted, corporate tax made publicly traded firms' returns available to the general public); Dave Hartnett, The Link Between Taxation and Corporate Governance, in TAX AND CORPORATE GOVERNANCE 4 (Wolfgang Schön ed. 2008) ("Some countries publish tax returns ... to produce ... transparency").

${ }^{159}$ See Hanlon \& Slemrod, supra note 153, at 126 ("in order to maximize the value of the firm, shareholders would like to minimize corporate tax payments net of the private costs of doing so").

${ }^{160}$ See Hanlon \& Slemrod, supra note 153, at 127 (noting that stock price declines associated with news that corporations are involved in tax shelters tend to be less severe for firms with high effective tax rates; suggesting the
} 
a result, rules requiring the disclosure of tax risks, such as FAS 48, may not advance shareholder interests; while it may become easier to evaluate, tax risk is magnified if the disclosure attracts government scrutiny. ${ }^{161}$ In general, shareholders have reason to value tax planning even more than managers, since shareholders do not bear the same downside risks. If the firm is caught being too aggressive, shareholders are unlikely to bear reputational costs, while managers could lose their jobs and even go to jail. ${ }^{162}$ This is an agency cost, but a socially useful one.

Just as shareholders may not think they share interests with the tax authorities, the reverse can also be true. The priority of tax authorities is to collect tax, not to protect shareholders. As long as a firm is paying its taxes, tax collectors may not care about earnings manipulation or diversion. ${ }^{163}$ Indeed, in a high-profile German case, tax authorities did not intervene even though they knew managers were defrauding shareholders. ${ }^{164}$

\section{Conclusion}

The bottom line, then, is that tax affects managerial agency costs in a broad range of ways. In the U.S., tax influences how managers are paid, how they allocate the firm's resources, and how effectively they are monitored by shareholders, as well as by the tax authorities themselves. The overall record is unimpressive, but not uniformly so.

Indeed, four effects are particularly useful in mitigating agency costs. First, tax rules discourage executives from hedging stock option grants, thereby backstopping the incentives these grants are supposed to create. Second, tax rules promote the use of equity compensation in venture-capital-backed startups. Third, the tax advantages of leverage pressure managers to issue debt, and thus to generate sufficient earnings to pay interest. Fourth, the tax on intercompany dividends discourages pyramidal ownership. Notably, only the last of these was (arguably) intended by Congress as a response to agency costs.

reason for this difference may be that shareholders value the fact that firms are "not as 'tax passive' as previously believed"); Katharine D. Drake, Stephen J. Lusch \& James M. Stekelberg, Investor valuation of tax avoidance and the uncertainty of tax outcomes: Evidence from the pre- and post-FIN 48 periods, Working Paper, University of Arizona, Eller College of Management (March 2014) (investors generally value tax avoidance, although they discount it for tax risk); Michelle Hutchens \& Sonja Rego, Tax Risk and the Cost of Equity Capital, Working Paper, Indiana University (September 2013) (investors do take tax risk into account in valuing companies, especially now that there is an accounting requirement for increased disclosure of tax risk); Mihir A. Desai \& Dhammika Dharmapala, Corporate Tax Avoidance and Firm Value, 91 REV. ECON. AND STAT. 537 (2009) (tax avoidance is positively related to firm value in well governed firms, but negatively-related in poorly governed firms).

${ }^{161}$ Schön, supra note 8, at 50.

${ }^{162}$ Incentives may vary among managers as well. Tax directors could have higher appetites for tax risk than other managers, for instance, since successful planning can enhance their reputations. See Schön, supra note 8, at 49. Yet the other side of the coin is that they have more to lose from unsuccessful planning.

${ }^{163}$ Merle Erickson, Michelle Hanlon \& Edward L. Maydew, How Much Will Firms Pay for Earnings That Do Not Exist? Evidence of Taxes Paid on Allegedly Fraudulent Earnings, 79 ACCOUNTING REV. 387 (2004) (firms paid significant tax on fraudulent earnings, presumably because they worried more about IRS monitoring than shareholder monitoring).

${ }^{164}$ Schön, supra note 8, at 60. (discussing the Baden-Wurteemberg decision, in which the court found for the state in a suit where shareholders sued because the state's tax authorities knew of fraud but did not intervene to stop it). 
At the same time, three tax effects are especially pernicious. First, to the extent that tax offers a reason (or excuse) not to pay dividends, managers have more control over retained earnings, which they can use in self-interested ways. Second, it is unfortunate that managers can invoke tax losses as an argument against being acquired, since these losses are often evidence of poor management. Third, governance can suffer when tax supplies a reason (or excuse) to reincorporate in jurisdictions with weaker corporate law protections.

The reality, though, is that tax authorities are unlikely to focus on these effects. Their institutional mission is to collect taxes, not to target managerial agency costs. It is not surprising, then, that virtually all the Pigouvian measures discussed here are imperfectly tailored or even misguided. Accidental effects do not give any more cause for optimism. Some will escape the notice of government tax experts, while others will not be considered a priority. Given this track record, Congress should use tax only sparingly, if at all, to target agency costs.

Even so, there is value in charting these effects. In some (rare) cases, the tax authorities may be willing and able to adjust tax rules in ways that reduce agency costs. A more promising avenue, though, is to educate corporate governance experts about these tax effects, so they can account for them when tailoring corporate and securities law responses to agency costs. 